Terr. Atmos. Ocean. Sci., Vol. 17, No. 4, 981-1007, December 2006

\title{
Mineralogy and Physical Properties of Cored Sediments from the Gas Hydrate Potential Area of Offshore Southwestern Taiwan
}

\author{
Wei-Teh Jiang ${ }^{1,}{ }^{*}$, Ju-Chin Chen ${ }^{2}$, Bo-Jiun Huang ${ }^{2}$, Chun-Jung Chen ${ }^{1}$, Yung-Tan Lee ${ }^{2}$, \\ Pin-Ru Huang ${ }^{1}$, Chieh-Chia Lung ${ }^{1}$, and Shao-Wei Huang ${ }^{2}$
}

(Manuscript received 12 September 2005, in final form 10 August 2006)

\begin{abstract}
Cored sediments from the gas hydrate prospect area offshore southwestern Taiwan exhibit porosities, water contents, and bulk densities comparable to sediments in other gas-hydrate potential areas. Short-distance transport and rapid deposition of the sediments are implied by their poor sorting and detrital and clay mineralogy. These features and the organicrich nature of the sediments present an environment suitable for formation of gas hydrates. High methane concentrations of porewaters and gas-escape structures of the sediments further imply possible occurrence of gas hydrates in the region. Prominent overgrowth microstructures on authigenic pyrite framboids at shallow depths are consistent with sulfate reduction and pyrite precipitation related to migration and oxidation of methane possibly released from gas hydrate zones at later stages of early diagenesis.
\end{abstract}

(Key words: Gas hydrate, Taiwan, Porosity, Density, Clay minerals, Pyrite)

\section{INTRODUCTION}

Geophysical data collected in the southwestern offshore area of Taiwan indicate that bottom simulating reflectors (BSR) are widely distributed and that gas hydrates may exist in the continental slope of the South China Sea and the accretionary wedge near southern Taiwan (Liu et al. 2006; Schnürle et al. 2006). The Central Geological Survey of the Ministry of Economic Affairs has sponsored a comprehensive geophysical, geological and geochemical survey in the target area (Fig. 1) since the beginning of 2004 in order to evaluate the genesis and probable reserves of gas hydrate in that area.

\footnotetext{
${ }^{1}$ Department of Earth Sciences, National Cheng Kung University, Tainan, Taiwan, ROC

2 Institute of Oceanography, National Taiwan University, Taipei, Taiwan, ROC

* Corresponding author address: Prof. Wei-Teh Jiang, Department of Earth Sciences, National Cheng Kung University, Tainan, Taiwan, ROC; E-mail: atwtj@mail.ncku.edu.tw
} 


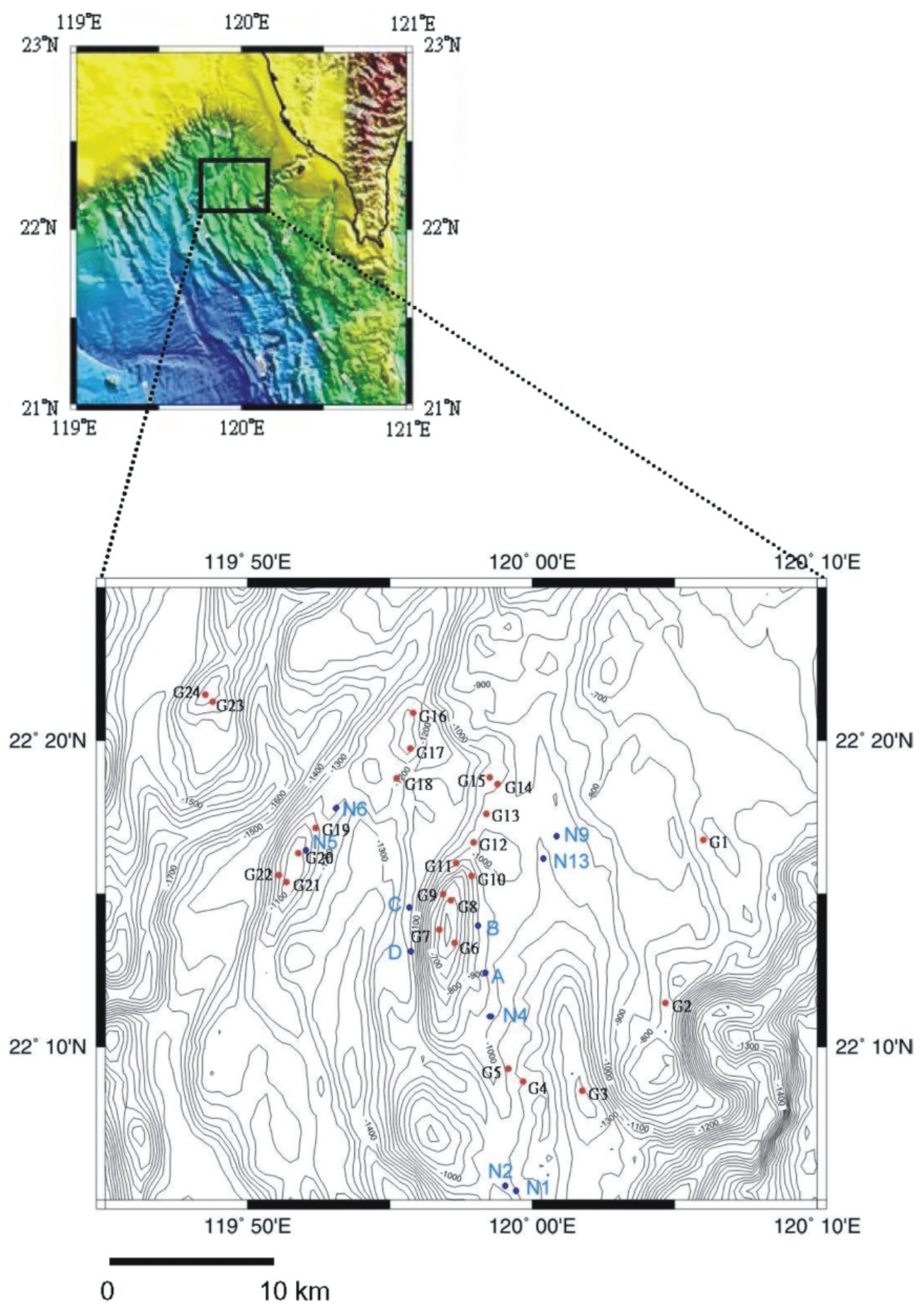

Fig. 1. Location map of sampling stations. 
Taiwan offers a typical example of present-day arc-continent collision between the Luzon arc of the Philippine Sea Plate and the Chinese continental margin. Suppe (1984) concluded that the collision, flipping and back-arc spreading have been propagating along the continental margin at essentially identical rates since the late Pliocene. The active and relict accretionary wedges on both sides of Luzon are interpreted as resulting from two changes in the direction of subduction by the Luzon arc (Bowin et al. 1978). In the vicinity of the gas-hydrate target area off SW Taiwan, the Kaoping slope is considered to be part of the accretionary wedge related to the subduction of the Manila Trench (Huang et al. 1997, 2000; Liu et al. 1997).

The target area off SW Taiwan (Fig. 1) has a high sedimentation rate of $100 \sim 500 \mathrm{~cm} \mathrm{ky}^{-1}$ on the basis of carbon-14 dating by Horng (2005). The sediments may be mainly derived from the southern part of the Western Foothills of Taiwan where clastic sandy and muddy formations of Miocene to Pliocene age are widely distributed. The western slope of the Central Range where slate formation is dominant may also provide some materials to the target area (Huang et al. 2004). These clastic materials derived from Taiwan may have been transported to the target area through the submarine canyons off SW Taiwan, such as Kaoping Canyon, Kaohsiung Canyon, and Funliao Canyon (Fu et al. 1997).

Gas hydrate may exist in the accretionary fold-thrust belt off SW Taiwan, which is characterized by high sedimentation rates and the common presence of mud volcanoes (Sun and Liu 1993). This potential gas-hydrate target area displays characteristics similar to those of the gas hydrate-bearing Nankai accretionary wedge off SE Japan (Matsumoto et al. 2004). It is an active accretionary wedge that contains widely distributed bottom simulating seismic reflectors, and it is composed largely of rapidly deposited terrigenous sediments (turbidites). In this paper, we describe the mineralogy and physical properties of cored sediments in the target area, discuss their geological significance, and examine the relationship between the sediment properties and the potential occurrence of gas hydrates in the region.

\section{ANALYTICAL METHODS}

\subsection{Bulk Sediment Analysis}

The samples for measurements of physical properties and bulk mineralogy were selected from 16 piston cores taken by the R/V Ocean Resesrcher I in October 2003 (ORI-697) and May 2004 (ORI-718). The basic data of the sampling sites including longitude, latitude, water depth, core length and lithology are listed in Table 1. Long piston cores were preferentially selected for analysis during this stage. Analysis of other cored samples were done in a later stage and will be reported elsewhere. Grain-size analyses of the cored sediments were performed by a laser particle analyzer. Mineral identification of bulk sediments was carried out by X-ray diffraction on a Philips PW1830 X-ray diffractometer with $\mathrm{Cu}$ radiation and nickel filter.

Porosity of the cored sediments was estimated by "summation of fluids" method as outlined by LeRoy et al. (1977). Bulk density of the samples was calculated based on the weight and volume of the bulk sediments using a fixed-volume steel ring with inner diameter of $3 \mathrm{~cm}$. Water content of the cored sediments was calculated based on the weight loss of the sediments after heating in an oven at $105^{\circ} \mathrm{C}$ for $72 \mathrm{hrs}$. 
Table 1. Basic data of sampling stations.

\begin{tabular}{|c|c|c|c|c|c|}
\hline Station & Water depth (m) & Longitude & Latitude & Core length $(\mathrm{cm})$ & Lithology \\
\hline G1 & 723 & $120^{\circ} 06.37^{\prime}$ & $22^{\circ} 16.40^{\prime}$ & 225 & Mud with pyrite \\
\hline G2 & 718 & $120^{\circ} 04.70^{\prime}$ & $22^{\circ} 11.48^{\prime}$ & 56 & Mud \\
\hline G3 & 1363 & $120^{\circ} 01.55^{\prime}$ & $22^{\circ} 08.57^{\prime}$ & 307.5 & Mud grey in color \\
\hline G4 & 1061 & $119^{\circ} 59.69^{\prime}$ & $22^{\circ} 08.84^{\prime}$ & 123 & $\begin{array}{l}\text { Soft mud with } \\
\text { abundant shells }\end{array}$ \\
\hline G5 & 1010 & $119^{\circ} 58.97^{\prime}$ & $22^{\circ} 09.40^{\prime}$ & 295 & Sandy mud \\
\hline G6 & 567 & $119^{\circ} 57.07^{\prime}$ & $22^{\circ} 13.57^{\prime}$ & 57 & Mud \\
\hline G7 & 608 & $119^{\circ} 56.68^{\prime}$ & $22^{\circ} 13.90^{\prime}$ & 135 & Mud \\
\hline G9B & 675 & $119^{\circ} 56.85^{\prime}$ & $22^{\circ} 14.99^{\prime}$ & 354 & Mud \\
\hline G10 & 767 & $119^{\circ} 57.49^{\prime}$ & $22^{\circ} 15.82^{\prime}$ & 97 & Mud \\
\hline G11 & 813 & $119^{\circ} 57.31^{\prime}$ & $22^{\circ} 15.97^{\prime}$ & 20 & $\begin{array}{l}\text { Greyish black } \\
\text { hardened mud }\end{array}$ \\
\hline G12 & 936 & $119^{\circ} 57.91^{\prime}$ & $22^{\circ} 16.65^{\prime}$ & 18 & Hardened mud \\
\hline G14 & 1049 & $119^{\circ} 58.72^{\prime}$ & $22^{\circ} 18.68^{\prime}$ & 157 & $\begin{array}{l}\text { Soft mud with } \\
\text { gravels }\end{array}$ \\
\hline G15 & 968 & $119^{\circ} 58.64^{\prime}$ & $22^{\circ} 18.71^{\prime}$ & 180 & $\begin{array}{l}\text { Soft mud with } \\
\text { fossils }\end{array}$ \\
\hline G16 & 1076 & $119^{\circ} 55.81^{\prime}$ & $22^{\circ} 20.90^{\prime}$ & 8 & Hardened mud \\
\hline G17 & 1010 & $119^{\circ} 55.63^{\prime}$ & $22^{\circ} 19.81^{\prime}$ & 114 & Hardened mud \\
\hline G18 & 1217 & $119^{\circ} 55.22^{\prime}$ & $22^{\circ} 18.78^{\prime}$ & 22 & $\begin{array}{l}\text { Grey hardened } \\
\text { mud with sand }\end{array}$ \\
\hline G19 & 1178 & $119^{\circ} 52.49^{\prime}$ & $22^{\circ} 17.30^{\prime}$ & 229 & Mud \\
\hline G21 & 1277 & $119^{\circ} 52.88^{\prime}$ & $22^{\circ} 15.27^{\prime}$ & 349 & Mud \\
\hline G22 & 1104 & $119^{\circ} 51.08^{\prime}$ & $22^{\circ} 15.61^{\prime}$ & 472 & Soft mud \\
\hline G23 & 1229 & $119^{\circ} 48.90^{\prime}$ & $22^{\circ} 21.15^{\prime}$ & 340 & Hardened mud \\
\hline G24 & 1097 & $119^{\circ} 48.50^{\prime}$ & $22^{\circ} 21.50^{\prime}$ & 480 & Grey soft mud \\
\hline $\mathrm{A}$ & 964 & $119^{\circ} 58.43^{\prime}$ & $22^{\circ} 12.49^{\prime}$ & 393 & Mud \\
\hline B & 948 & $119^{\circ} 58.15^{\prime}$ & $22^{\circ} 14.00^{\prime}$ & 145 & Mud \\
\hline $\mathrm{C}$ & 1177 & $119^{\circ} 55.68^{\prime}$ & $22^{\circ} 14.67^{\prime}$ & 218 & Mud \\
\hline $\mathrm{D}$ & 1090 & $119^{\circ} 55.71^{\prime}$ & $22^{\circ} 13.25^{\prime}$ & 352 & Mud \\
\hline N1 & 1082 & $119^{\circ} 59.37^{\prime}$ & $22^{\circ} 05.30^{\prime}$ & 473 & $\begin{array}{l}\text { Grey hardened } \\
\text { mud }\end{array}$ \\
\hline N2 & 1068 & $119^{\circ} 58.89^{\prime}$ & $22^{\circ} 05.66^{\prime}$ & 183 & $\begin{array}{c}\text { Sand in the upper } \\
\text { part, mud in the } \\
\text { lower part }\end{array}$ \\
\hline N4 & 973 & $119^{\circ} 58.48^{\prime}$ & $22^{\circ} 11.07^{\prime}$ & 535 & $\begin{array}{l}\text { Soft mud with } \\
\text { abundant shells }\end{array}$ \\
\hline N5 & 940 & $119^{\circ} 51.89^{\prime}$ & $22^{\circ} 16.20^{\prime}$ & 50 & $\begin{array}{l}\text { Grey hardened } \\
\text { mud }\end{array}$ \\
\hline N6 & 1164 & $119^{\circ} 53.25^{\prime}$ & $22^{\circ} 17.80^{\prime}$ & 456 & Soft mud \\
\hline N8 & 911 & $119^{\circ} 49.55^{\prime}$ & $22^{\circ} 25.66^{\prime}$ & 215 & Soft mud \\
\hline N9 & 963 & $120^{\circ} 00.79^{\prime}$ & $22^{\circ} 17.00^{\prime}$ & 304 & Sandy mud \\
\hline N13 & 1000 & $120^{\circ} 00.39^{\prime}$ & $22^{\circ} 16.08^{\prime}$ & 563 & Soft mud \\
\hline
\end{tabular}




\subsection{Clay Mineral Analysis}

Preparation of clay fractions followed the methods of Kunze and Dixon (1986) and Whittig and Allardice (1986). Samples were washed three times with deionized water by a centrifuge to remove seawater. Dissolution of soluble salts and carbonates was done with sodium acetate buffer and organic matter was removed by hydrogen peroxide. Less than $2 \mu \mathrm{m}$ fractions were separated from the pre-treated cored sediments by a centrifuge at $20^{\circ} \mathrm{C}$. The clay fractions were oriented on glass slides using the pipette method after $\mathrm{Mg}$ saturation with magnesium chloride and acetate. X-ray diffraction (XRD) analyses of the oriented clay fractions were carried out utilizing a Rigaku 4056A2 B2701 diffractometer (Cu radiation and Ni filter). X-ray diffraction patterns of both air-dried clay fractions and those followed by solvation with ethylene glycol were digitally recorded with a computer system. Identification of clay minerals was based on the methods illustrated by Whittig and Allardice (1986) and Moore and Reynolds (1989). Semi-quantitative analyses of the proportions of different clay minerals were obtained from XRD patterns of the oriented clay fractions treated with ethylene glycol. The integrated areas of the reflections with $d$ values of $\sim 1.7, \sim 1.0$, and $\sim 0.7 \mathrm{~nm}\left(\sim 5.2^{\circ}, \sim 8.9^{\circ}\right.$, and $\left.\sim 12.5^{\circ} 2 \theta\right)$ were weighted by factors of 1,4 , and 2 to calculate the proportions of smectite, illite, and chlorite, respectively. Kaolinite was not detected in the clay fractions (see below) and was therefore excluded from the analyses. Detailed procedures, empirical formulae, and theoretical consideration of clay-mineral quantification are outlined in Johns et al. (1954) and Biscaye (1965). The peak widths at half-height maxima of $\sim 1.0$ and $\sim 0.7 \mathrm{~nm}$ reflections in the XRD patterns of clay fractions after solvation with ethylene glycol were measured as illite and chlorite crystallinity indices, respectively. The studied samples were collected at a depth interval of $50 \mathrm{~cm}$. A total of 140 specimens from 22 sampling stations were analyzed. Fifteen of the selected sampling stations are identical to those chosen for measurements of physical properties. Additional samples were selected from longer piston cores for better regional comparison.

\subsection{Petrographic Analysis}

A polished thin section of the deepest sample (better compacted) of each piston core was used for scanning electron microscope analysis to identify accessory minerals. A total of 18 samples from 18 selected stations were analyzed. The sampling stations were selected so that they can cover the area of the described physical-property and clay-mineral analyses as much as possible. A JEOL JSM-840A scanning electron microscope coupled with a Link X-ray energy-dispersive spectrometer system was used in this study.

\section{MINERALOGY OF THE CORED SEDIMENTS}

\subsection{Bulk Sediments}

The cored sediments are mostly muds with $>4 \phi$ fractions averaging $95.4 \%$ of the total sediments. The percentages of mud show little variations with core depths (Table 2).

Major minerals of bulk sediments identified by XRD include quartz, feldspar, illite, chlorite ( \pm kaolinite), and calcite. The intensity ratios of feldspar $\left(27.8^{\circ}\right) /$ quartz $\left(20.9^{\circ}\right)$, illite $\left(8.9^{\circ}\right) /$ 
Table 2. Sand and mud contents, porosity, bulk density and water content of the cored sediments.

\begin{tabular}{|c|c|c|c|c|c|}
\hline Sample* & $\begin{array}{c}\text { Sand }(<4 \text { phi) } \\
\text { wt\% } \%\end{array}$ & $\begin{array}{c}\text { Mud (>4 phi) } \\
\text { wt\% }\end{array}$ & $\begin{array}{c}\text { Bulk density } \\
\left(\mathrm{g} / \mathrm{cm}^{3}\right)\end{array}$ & $\begin{array}{c}\text { Water content } \\
(\%)\end{array}$ & $\begin{array}{c}\text { Porosity } \\
(\text { V\% })\end{array}$ \\
\hline G1 10 15 & 1.73 & 98.27 & 1.85 & 19.46 & 31.88 \\
\hline G1 90 95 & 0.60 & 99.40 & 1.95 & 19.99 & 32.18 \\
\hline G1 160 165 & 1.08 & 98.92 & 1.90 & 17.78 & 28.64 \\
\hline G1 210 215 & 1.45 & 98.55 & 1.99 & 12.13 & 19.14 \\
\hline G2 40 45 & 2.32 & 97.68 & 2.10 & 7.57 & 14.25 \\
\hline G2 90 95 & 3.44 & 96.56 & 2.18 & 11.01 & 20.93 \\
\hline G2 140 145 & 4.02 & 95.98 & 2.22 & 5.61 & 10.60 \\
\hline G3 10 15 & 5.93 & 94.07 & 2.03 & 24.14 & 36.21 \\
\hline G3 140 145 & 0.30 & 99.70 & 2.09 & 9.45 & 15.84 \\
\hline G3 240 245 & 0.18 & 99.82 & 1.91 & 29.83 & 56.87 \\
\hline G3 340 345 & 0.87 & 99.13 & 1.86 & 31.88 & 57.77 \\
\hline G5A 10 15 & 26.91 & 73.09 & 1.79 & 34.36 & 59.90 \\
\hline G5A 90 95 & 26.00 & 74.00 & 1.95 & 31.12 & 59.08 \\
\hline G5A 160 165 & 32.17 & 67.83 & 1.83 & 33.04 & 58.94 \\
\hline G5A 240 245 & 27.01 & 72.99 & 1.91 & 33.05 & 61.35 \\
\hline G6 10 15 & 1.26 & 98.74 & 1.91 & 31.33 & 58.32 \\
\hline G6 90 95 & 0.84 & 99.16 & 1.88 & 32.09 & 58.87 \\
\hline G6 160 165 & 0.27 & 99.73 & 1.95 & 29.84 & 56.73 \\
\hline G6 240 245 & 0.23 & 99.77 & 1.88 & 32.25 & 59.08 \\
\hline G10 10 15 & 1.20 & 98.80 & 1.95 & 30.76 & 58.46 \\
\hline G10 40 45 & 0.09 & 99.91 & 2.01 & 28.42 & 55.64 \\
\hline G10 60 65 & 0.22 & 99.78 & 1.97 & 28.02 & 53.85 \\
\hline G10 90 95 & 0.16 & 99.84 & 1.98 & 28.30 & 54.53 \\
\hline G15 10 15 & 36.24 & 63.76 & 1.88 & 33.79 & 61.70 \\
\hline G15 90 95 & 6.75 & 93.25 & 1.94 & 32.18 & 60.66 \\
\hline G15 160 165 & 2.28 & 97.72 & 1.93 & 33.10 & 62.11 \\
\hline G15 240 245 & 4.51 & 95.49 & 1.91 & 31.57 & 58.80 \\
\hline G17 10 15 & 0.79 & 99.21 & 2.01 & 30.29 & 59.15 \\
\hline G17 40 45 & 0.53 & 99.47 & 1.97 & 30.58 & 58.60 \\
\hline G17 60 65 & 0.84 & 99.16 & 1.88 & 30.80 & 56.26 \\
\hline G19 10 15 & 0.66 & 99.34 & 1.84 & 33.00 & 59.22 \\
\hline G19 90 95 & 0.10 & 99.90 & 1.84 & 32.01 & 57.36 \\
\hline
\end{tabular}


Table 2. (Continued)

\begin{tabular}{|c|c|c|c|c|c|}
\hline Sample* & $\begin{array}{c}\text { Sand (<4 phi) } \\
\text { wt\% }\end{array}$ & $\begin{array}{c}\text { Mud ( }>\text { phi }) \\
\text { wt\% }\end{array}$ & $\begin{array}{c}\text { Bulk density } \\
\left(\mathrm{g} / \mathrm{cm}^{3}\right)\end{array}$ & $\begin{array}{c}\text { Water content } \\
(\%)\end{array}$ & $\begin{array}{c}\text { Porosity } \\
(\mathrm{V} \%)\end{array}$ \\
\hline G19 160 165 & 0.11 & 99.89 & 1.86 & 31.27 & 56.74 \\
\hline G19 210 215 & 0.08 & 99.92 & 1.84 & 31.94 & 57.36 \\
\hline G21 10 15 & 0.69 & 99.31 & 1.67 & 35.58 & 57.84 \\
\hline G21 110 115 & 0.61 & 99.39 & 1.66 & 40.68 & 65.83 \\
\hline G21 210 215 & 0.46 & 99.54 & 1.64 & 42.70 & 68.10 \\
\hline G21 310 315 & 0.33 & 99.67 & 1.61 & 43.37 & 68.03 \\
\hline G22 13 18 & 1.46 & 98.54 & 1.69 & 38.67 & 63.55 \\
\hline G22 95 100 & 1.04 & 98.96 & 1.71 & 37.66 & 62.73 \\
\hline G22 245 250 & 0.90 & 99.10 & 1.72 & 37.24 & 62.52 \\
\hline G22 345 350 & 1.01 & 98.99 & 1.71 & 37.07 & 61.76 \\
\hline G22 445 450 & 4.21 & 95.79 & 1.75 & 35.42 & 60.46 \\
\hline G23 10 15 & 1.61 & 98.39 & 1.74 & 41.49 & 75.54 \\
\hline G23 140 145 & 2.96 & 97.04 & 1.81 & 32.63 & 57.63 \\
\hline G23 290 295 & 1.97 & 98.03 & 1.82 & 31.60 & 55.91 \\
\hline G23 410 415 & 5.30 & 94.70 & 1.86 & 31.33 & 56.74 \\
\hline N4 13 18 & 6.40 & 93.60 & 1.90 & 30.33 & 56.19 \\
\hline N4 95 100 & 5.84 & 94.16 & 1.90 & 29.72 & 54.88 \\
\hline N4 245 250 & 1.61 & 98.39 & 1.88 & 33.87 & 61.90 \\
\hline N4 345 350 & 3.57 & 96.43 & 1.85 & 30.91 & 55.57 \\
\hline N4 413 418 & 2.51 & 97.49 & 1.82 & 32.35 & 57.15 \\
\hline N4 513 518 & 4.37 & 95.63 & 1.89 & 30.42 & 55.98 \\
\hline N6 0 5 & 1.57 & 98.43 & 1.69 & 39.02 & 64.38 \\
\hline N6 95 100 & 2.94 & 97.06 & 1.74 & 36.96 & 62.66 \\
\hline N6 245 250 & 2.81 & 97.19 & 1.72 & 37.32 & 62.52 \\
\hline N6 345 350 & 2.82 & 97.18 & 1.76 & 35.49 & 60.80 \\
\hline N6 413 418 & 1.80 & 98.20 & 1.76 & 35.49 & 60.94 \\
\hline N8 13 18 & 1.58 & 98.42 & 1.94 & 28.35 & 53.57 \\
\hline N8 95 100 & 0.31 & 99.69 & 1.84 & 31.24 & 55.91 \\
\hline N8 195 200 & 0.22 & 99.78 & 1.77 & 35.66 & 61.56 \\
\hline N9 13 18 & 7.47 & 92.53 & 1.66 & 40.50 & 65.48 \\
\hline N9 95 100 & 26.12 & 73.88 & 1.97 & 22.23 & 42.62 \\
\hline N9 213 218 & 5.63 & 94.37 & 1.96 & 26.48 & 50.61 \\
\hline N9 295 300 & 2.40 & 97.60 & 1.82 & 32.85 & 58.25 \\
\hline
\end{tabular}

* Sample identification includes sampling station and depth interval in $\mathrm{cm}$. 
quartz $\left(20.9^{\circ}\right)$, chlorite $( \pm$ kaolinite $)\left(12.4^{\circ}\right) /$ quartz $\left(20.9^{\circ}\right)$ show limited variations with core depths (Fig. 2). However at certain stations, e.g., G2, feldspar (27.8 $) /$ quartz $\left(20.9^{\circ}\right)$ intensity ratios tend to increase with depth of the core. The calcite $\left(29.5^{\circ}\right) /$ quartz $\left(20.9^{\circ}\right)$ intensity ratios at station G5A is high due to the abundant occurrence of biogenic debris. At station G15, calcite $\left(29.5^{\circ}\right) /$ quartz $\left(20.9^{\circ}\right)$ intensity ratios tend to decrease with increasing core depth. Illite $\left(8.9^{\circ}\right)$ / quartz $\left(20.9^{\circ}\right)$ intensity ratios at G3 tend to decrease with increasing core depth, however the reverse is true at station G15. At stations G5A, G15, and N6, chlorite ( \pm kaolinite)
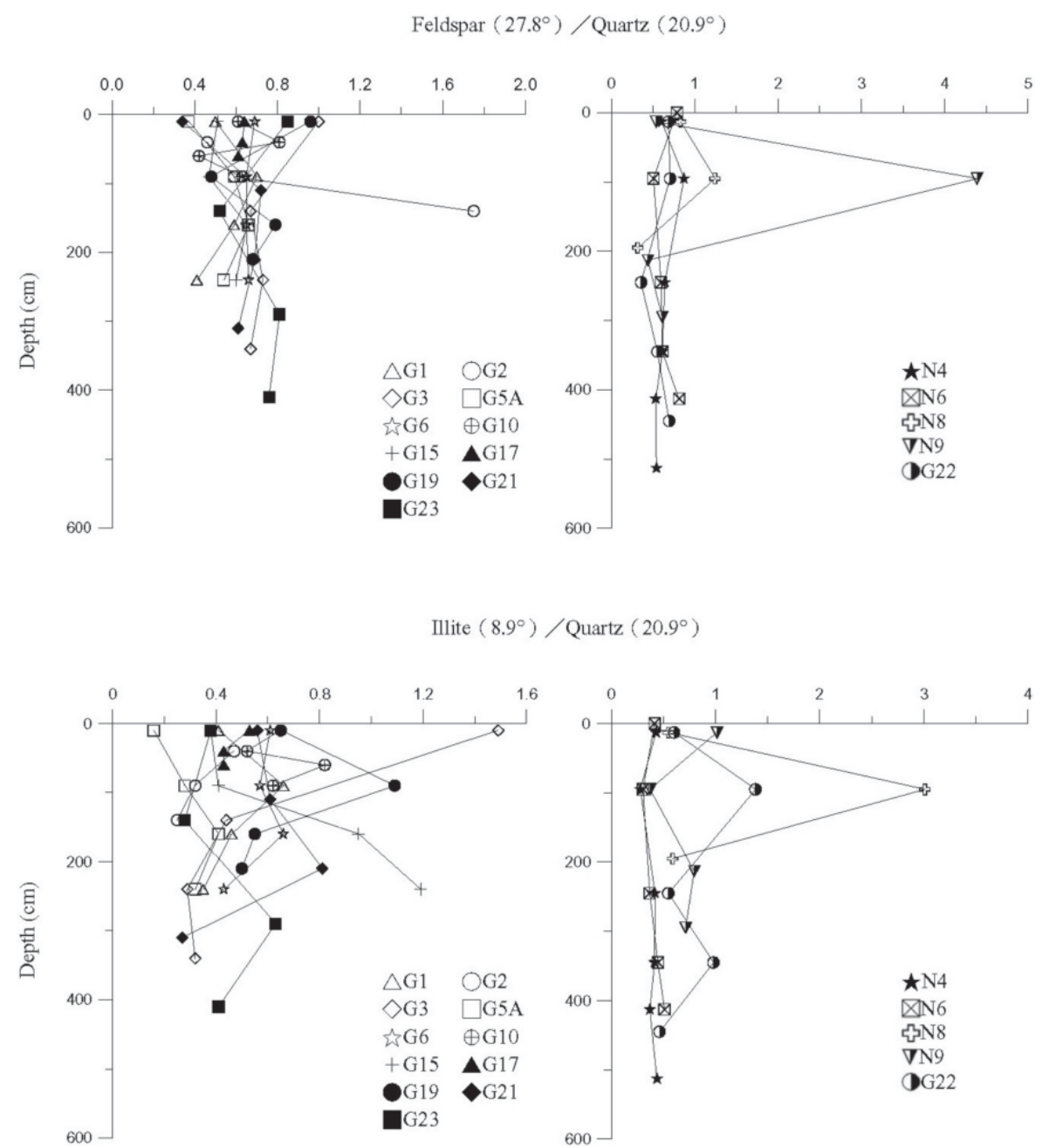

Fig. 2. Feldspar $\left(27.8^{\circ}\right) /$ Quartz $\left(20.9^{\circ}\right)$, Illite $\left(8.9^{\circ}\right) /$ Quartz $\left(20.9^{\circ}\right)$, Chlorite ( \pm kaolinite $)\left(12.4^{\circ}\right) /$ Quartz $\left(20.9^{\circ}\right)$, Calcite $\left(29.5^{\circ}\right) /$ Quartz $\left(20.9^{\circ}\right)$ intensity ratios variations with core depths. 
Chlorite $( \pm$ Kaolinite $)\left(12.4^{\circ}\right) /$ Quartz $\left(20.9^{\circ}\right)$

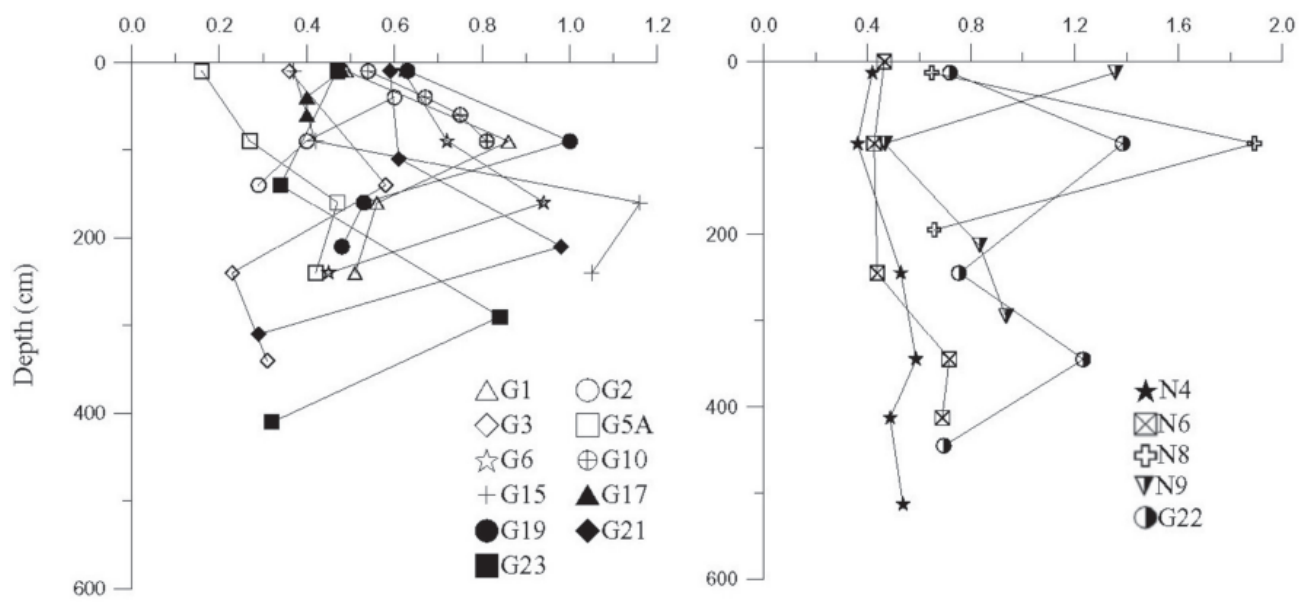

Calcite $\left(29.5^{\circ}\right) /$ Quartz $\left(20.9^{\circ}\right)$
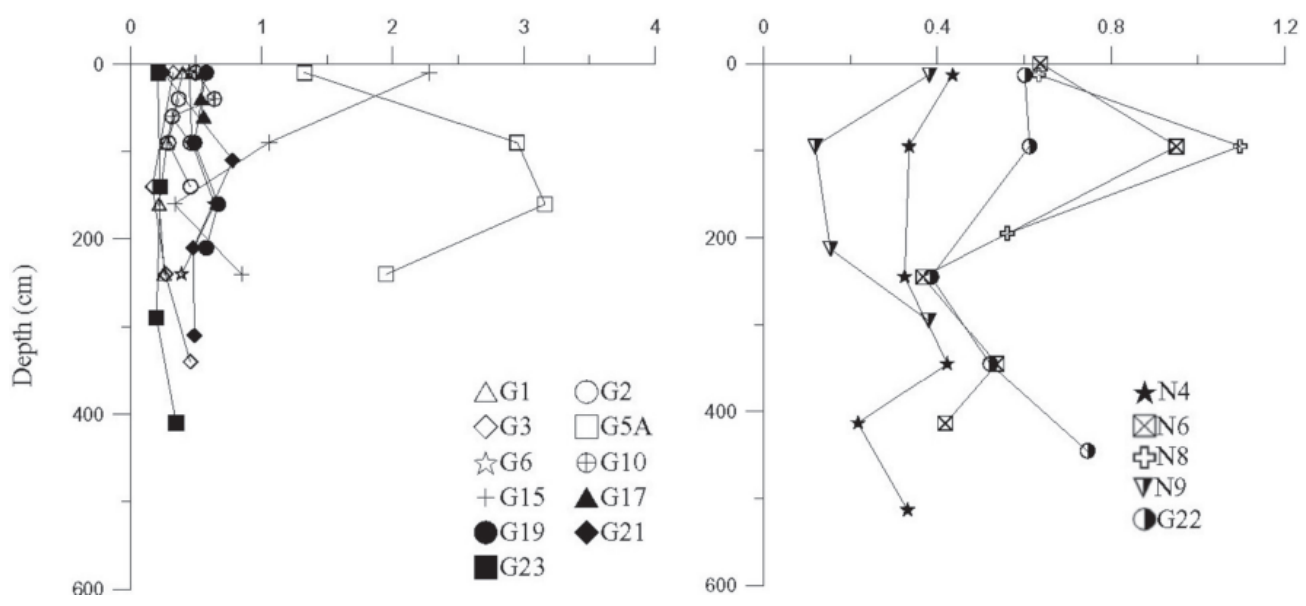

Fig. 2. (Continued).

$\left(12.4^{\circ}\right) /$ quartz $\left(20.9^{\circ}\right)$ intensity ratios tend to increase with increasing core depth up to $\sim 200 \mathrm{~cm}$ deep (Fig. 2), that may be related to the variations of source-rock mineralogy during deposition.

\subsection{Clay Fractions}

The XRD analyses of clay fractions suggest the presence of smectite, illite, and chlorite in 
all samples. The XRD patterns of a selected sample are given in Fig. 3. Partial displacement of the low-angle reflection from $\sim 5.9^{\circ} 2 \theta(\sim 1.5 \mathrm{~nm})$ to $5.2^{\circ} 2 \theta(\sim 1.7 \mathrm{~nm})$ after ethylene-glycol solvation suggests the presence of smectite. The peaks at $\sim 8.9^{\circ}(d=\sim 1.0 \mathrm{~nm}), \sim 17.7^{\circ}(\sim 0.50 \mathrm{~nm})$ and $\sim 26.7^{\circ}(\sim 0.33 \mathrm{~nm})$, and $\sim 6.2^{\circ}(\sim 1.42 \mathrm{~nm}), \sim 12.5^{\circ}(\sim 0.71 \mathrm{~nm}), \sim 18.8^{\circ}(\sim 0.47 \mathrm{~nm}), \sim 25.2^{\circ}$ $(\sim 0.35 \mathrm{~nm})$, and $31.6^{\circ} 2 \theta(2.8 \mathrm{~nm})$ represent 001,002 , and 003 reflections of illite and 001 , 002,003 , and 004 reflections of chlorite, respectively, assuming one-layer polytypism. The lack of $24.8^{\circ}-24.9^{\circ} 2 \theta$ reflection implies little or no kaolinite in the exemplified sample. Please also note that the illite 001 reflection is slightly skewed toward the low angle side and tends to become more symmetric and slightly narrowed after solvation with ethylene glycol, implying the presence of a small amount of smectite mixed layers. The aforementioned features are typical of all studied samples.

Semi-quantitative analyses indicate that the station-averaged clay mineral contents range from 45.7 to $66.6 \%$ for illite 20.8 to 32.9 for chlorite, and 4.2 to $27.4 \%$ for smectite (Table 3 ).

N6-P1 118-123

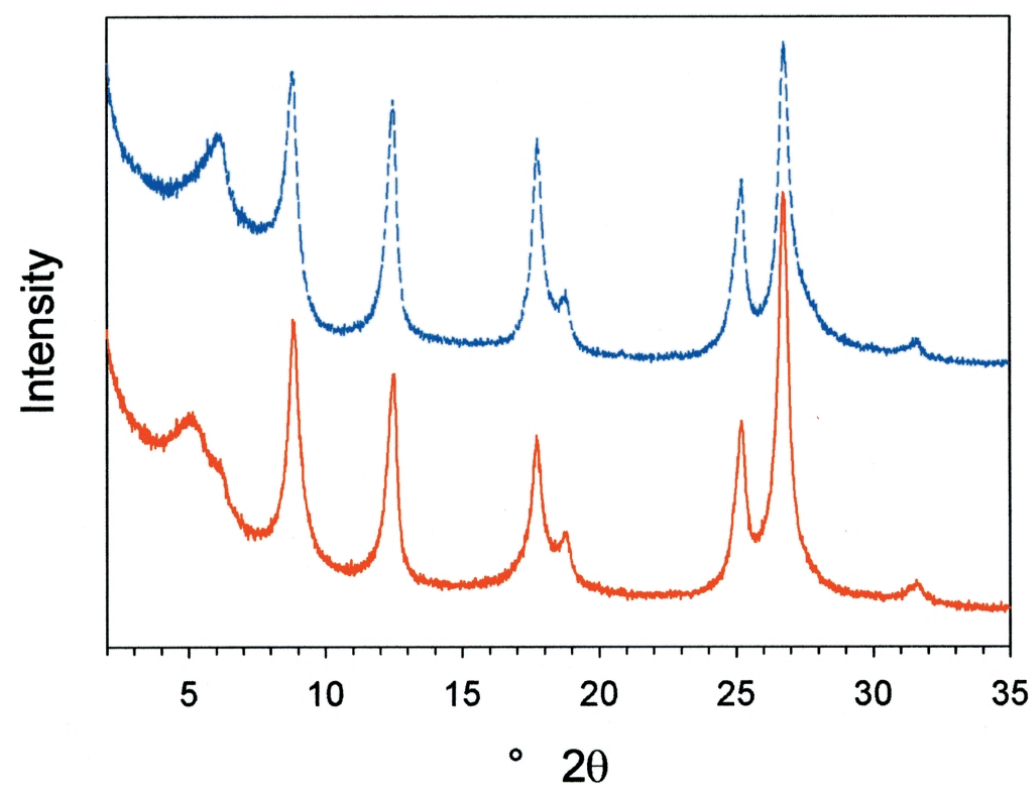

Fig. 3. X-ray powder diffraction patterns of Mg-saturated, oriented $<2 \mu \mathrm{m}$ fractions of a cored sediment collected at a depth of $118-123 \mathrm{~cm}$ from sampling station N6 of the gas-hydrate prospect area off southwestern Taiwan. Broken and solid lines were recorded from the clay fraction that was air dried and then subjected to ethylene glycol solvation, respectively. 
Table 3. Average smectite, illite, and chlorite percentages and illite and chlorite crystallinity indices $\left(\mathrm{IC}_{1.0 \mathrm{~nm}}\right.$ and $\mathrm{CC}_{0.7 \mathrm{~nm}}$ ) of clay fractions in cored sediments from various sampling stations in gas hydrate prospect area off SW Taiwan.

\begin{tabular}{|c|c|c|c|c|c|}
\hline Station & Smectite \% & Illite $\%$ & Chlorite \% & $\begin{array}{c}\mathrm{IC}_{1.0 \mathrm{~nm}} \\
\Delta^{\circ} 2 \theta\end{array}$ & $\begin{array}{c}\mathrm{CC}_{0.7 \mathrm{~nm}} \\
\Delta^{\circ} 2 \theta\end{array}$ \\
\hline A-P1 & $10.8 \pm 3.5^{*}$ & $59.8 \pm 3.4$ & $29.4 \pm 3.8$ & $0.39 \pm 0.05$ & $0.38 \pm 0.05$ \\
\hline B-P1 & $27.4 \pm 6.0$ & $45.7 \pm 6.4$ & $26.9 \pm 6.2$ & $0.30 \pm 0.13$ & $0.36 \pm 0.19$ \\
\hline C-P1 & $13.1 \pm 3.1$ & $58.5 \pm 3.3$ & $28.4 \pm 4.3$ & $0.33 \pm 0.03$ & $0.36 \pm 0.05$ \\
\hline D-P1 & $13.8 \pm 3.4$ & $59.3 \pm 4.2$ & $26.9 \pm 3.4$ & $0.43 \pm 0.05$ & $0.44 \pm 0.02$ \\
\hline G1-P1 & $5.9 \pm 3.3$ & $66.0 \pm 3.2$ & $28.1 \pm 3.4$ & $0.40 \pm 0.07$ & $0.43 \pm 0.04$ \\
\hline G2-P2 & $7.3 \pm 2.7$ & $61.4 \pm 0.9$ & $31.3 \pm 2.2$ & $0.47 \pm 0.04$ & $0.47 \pm 0.01$ \\
\hline G3-P1 & $4.2 \pm 2.8$ & $66.6 \pm 3.2$ & $29.2 \pm 1.1$ & $0.42 \pm 0.04$ & $0.42 \pm 0.01$ \\
\hline G4-P1 & $9.0 \pm 2.5$ & $63.6 \pm 3.7$ & $27.4 \pm 1.4$ & $0.30 \pm 0.12$ & $0.32 \pm 0.11$ \\
\hline G5A-P1 & $17.9 \pm 2.9$ & $54.8 \pm 4.9$ & $27.3 \pm 4.1$ & $0.39 \pm 0.09$ & $0.41 \pm 0.02$ \\
\hline G6-P1 & $9.3 \pm 3.4$ & $61.0 \pm 6.1$ & $29.7 \pm 3.3$ & $0.34 \pm 0.07$ & $0.38 \pm 0.04$ \\
\hline G10-P2 & $8.9 \pm 1.9$ & $58.5 \pm 13.7$ & $32.6 \pm 11.7$ & $0.38 \pm 0.16$ & $0.48 \pm 0.02$ \\
\hline G15-P1 & $13.1 \pm 2.9$ & $57.8 \pm 2.2$ & $29.1 \pm 2.7$ & $0.39 \pm 0.03$ & $0.40 \pm 0.01$ \\
\hline G17-P1 & $25.2 \pm 8.3$ & $54.0 \pm 10.3$ & $20.8 \pm 2.0$ & $0.47 \pm 0.06$ & $0.55 \pm 0.01$ \\
\hline G19-P1 & $12.8 \pm 3.6$ & $55.3 \pm 5.5$ & $31.8 \pm 8.7$ & $0.38 \pm 0.06$ & $0.45 \pm 0.03$ \\
\hline G21-P1 & $15.6 \pm 2.9$ & $56.9 \pm 1.6$ & $27.6 \pm 2.1$ & $0.41 \pm 0.03$ & $0.41 \pm 0.01$ \\
\hline G22-P1 & $14.2 \pm 5.5$ & $56.8 \pm 9.4$ & $29.0 \pm 8.0$ & $0.34 \pm 0.10$ & $0.34 \pm 0.11$ \\
\hline G23-P1 & $11.5 \pm 2.5$ & $55.6 \pm 3.1$ & $32.9 \pm 3.2$ & $0.38 \pm 0.05$ & $0.41 \pm 0.03$ \\
\hline G24-P1 & $12.9 \pm 2.9$ & $59.5 \pm 2.8$ & $27.6 \pm 2.0$ & $0.31 \pm 0.08$ & $0.33 \pm 0.09$ \\
\hline N4-P1 & $8.9 \pm 2.1$ & $59.4 \pm 3.2$ & $31.7 \pm 2.3$ & $0.33 \pm 0.05$ & $0.35 \pm 0.04$ \\
\hline N6-P1 & $15.4 \pm 3.7$ & $59.1 \pm 2.7$ & $25.5 \pm 2.3$ & $0.40 \pm 0.13$ & $0.37 \pm 0.12$ \\
\hline N9-P1 & $12.9 \pm 3.2$ & $59.0 \pm 2.8$ & $28.2 \pm 2.2$ & $0.30 \pm 0.03$ & $0.31 \pm 0.06$ \\
\hline N13-P1 & $7.5 \pm 3.0$ & $61.0 \pm 3.0$ & $31.4 \pm 2.6$ & $0.33 \pm 0.03$ & $0.34 \pm 0.04$ \\
\hline
\end{tabular}

* 1 standard deviation. 
Geographically, the samples from the western part of the studied region appear to have higher average values of smectite percentage than those in the eastern part (Fig. 4). The result of illite and chlorite crystallinity indices are given in Table 3. There are no systematic variations with sampling depths in terms of clay-mineral contents and crystallinity indices (e.g., Fig. 5).

\subsection{SEM Observation}

Qualitative X-ray energy-dispersive analyses suggest that accessory detrital grains including silt-sized quartz, plagioclase, chlorite-muscovite aggregates, epidote, biotite, actinolite, olivine, chlorite, muscovite, ilmenite, zircon, calcite (feraminifera skeletons), and iron-oxide minerals, and clay particles of montmorillonite and saponite are present in the studied samples

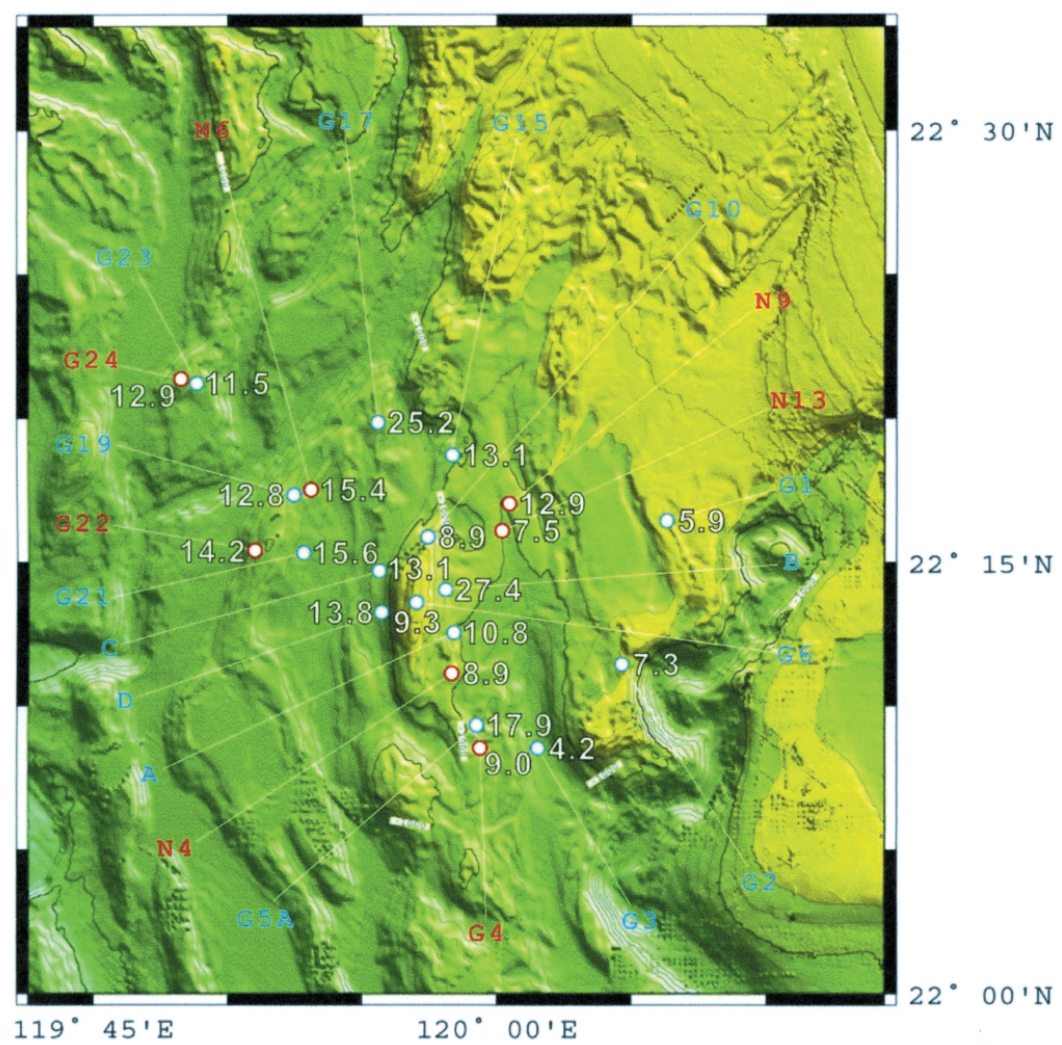

Fig. 4. Average values of smectite percentage in clay fractions of the analyzed piston cores off SW Taiwan. Blue and red circles are piston cores taken by R/V Ocean Researcher I in October 2003 (ORI-697) and May 2004 (ORI-718), respectively. 

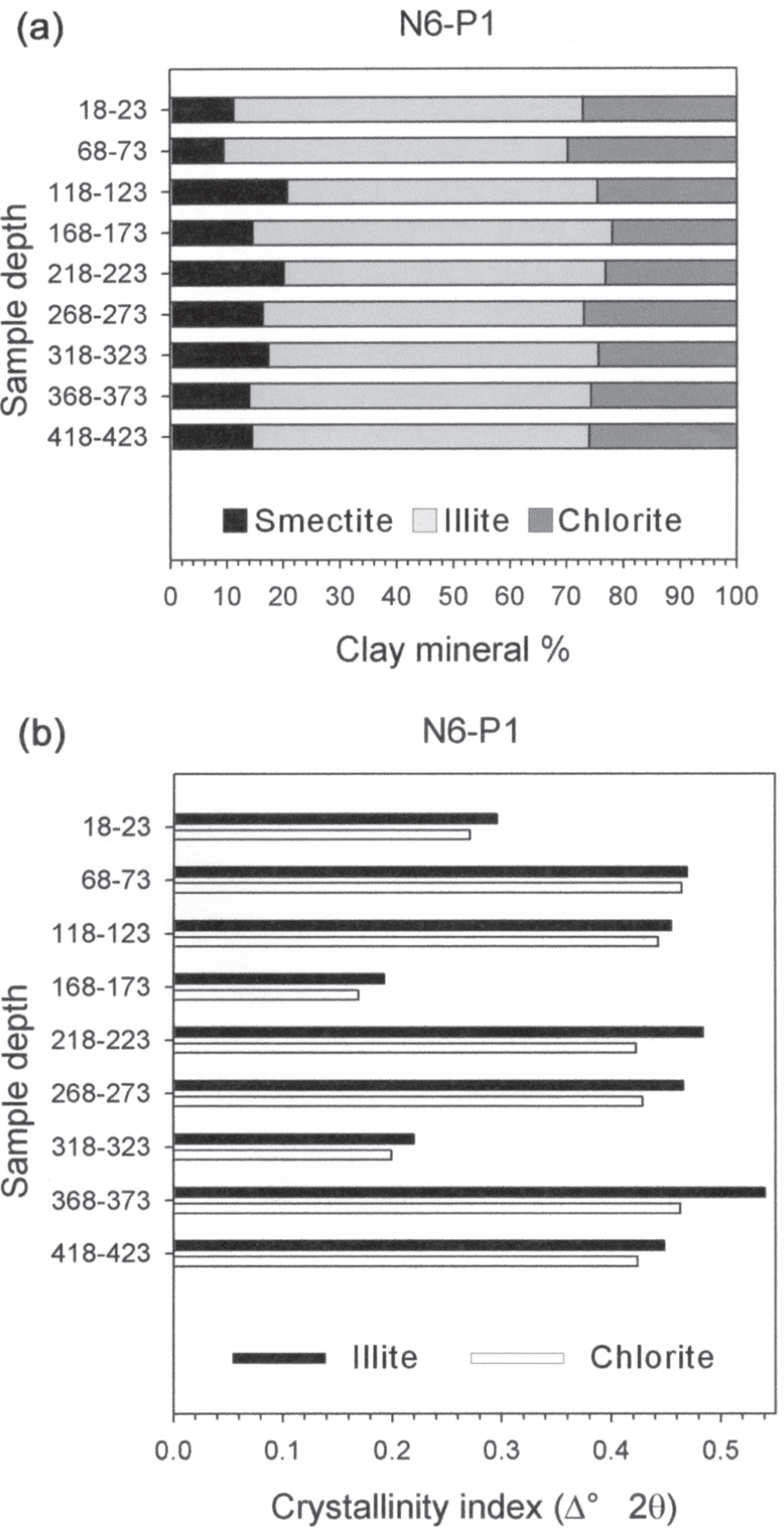

Fig. 5. (a) Accumulative histogram of clay-mineral contents and (b) illite and chlorite crystallinity indices of $<2 \mu \mathrm{m}$ fractions of sediments sampled from various depths $(\mathrm{cm})$ of a selected piston core (N6-P1) in gas-hydrate prospect area off SW Taiwan. 
(Fig. 6). In addition to the detrital materials, various minor amounts of authigenic pyrite are also present in all analyzed samples, mainly in the forms of framboids and individual euhedral crystals. Samples from station G4, G5A, G10, G15, G17, G22, N4, N6, N9, and N13 appear to have a relatively high content of pyrite. Overgrowth features in pyrite are common in samples from some of the piston cores, locally forming nodular microstructures (Fig. 7). The growth characteristics of pyrite are summarized in Table 4.

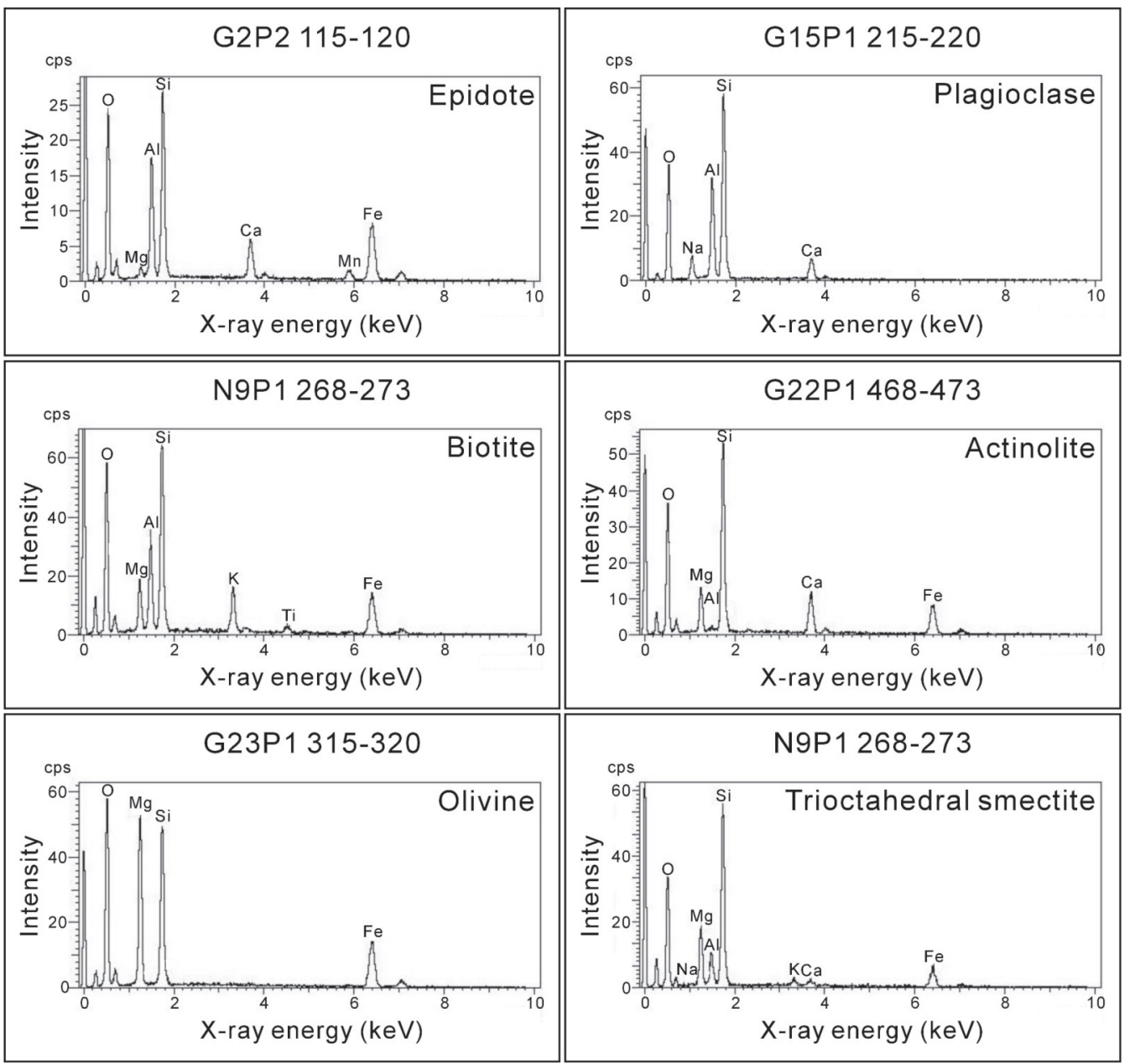

Fig. 6. X-ray energy-dispersive spectra of various mafic silicates of detrital source in selected samples from gas-hydrate prospect area off SW Taiwan. The label on top of each spectrum indicates piston-core identification and sampling depth $(\mathrm{cm})$ of the analyzed sample. 

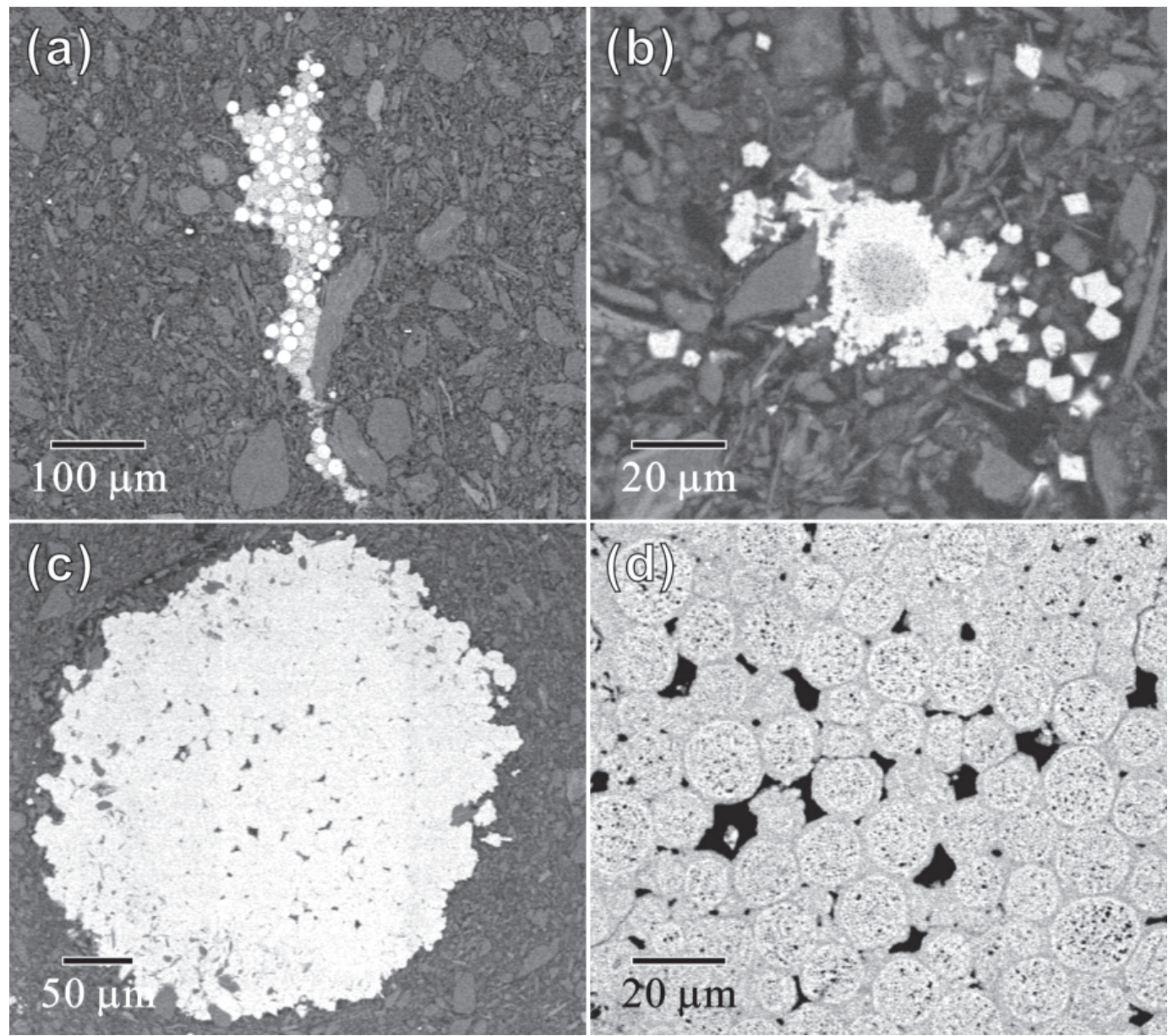

Fig. 7. Backscattered electron images of (a) pyrite framboids associated with an irregular aggregate of pyrite surrounded by a silicate-dominated matrix. (sample N9P1 268 - 273), (b) a pyrite framboid overgrown by euhedral pyrite crystals (G10P2 065 - 070), (c) a nodule consisting of numerous pyrite framboids and their overgrowth rims (G17P1 065 - 070), and (d) an enlargement of (c) showing overgrowth features on pyrite framboids.

\section{PHYSICAL PROPERTIES OF THE CORED SEDIMENTS}

The porosity, bulk density, and water content of cored sediments are listed in Table 2 . Porosity varies from 10.60 to 75.54 vol. $\%$ while water content ranges from 5.61 to $43.37 \%$ and bulk density varies from 1.61 to $2.22\left(\mathrm{~g} \mathrm{~cm}^{-3}\right)$. Porosity shows a slight decrease with core depth 
Table 4. Summary of pyrite occurrence in analyzed sediments from gas hydrate prospect area off SW Taiwan as observed by scanning electron microscopy.

\begin{tabular}{|c|c|c|c|c|c|c|}
\hline Sample & Station & Core & Depth (cm) & Framboids & $\begin{array}{c}\text { Euhedral } \\
\text { crystals }\end{array}$ & Overgrowth \\
\hline G1-P1 215-220 & G1 & P1 & $215-220$ & + & + & - \\
\hline G2-P2 115-120 & G2 & P2 & $115-120$ & + & + & - \\
\hline G3-P1 365-370 & G3 & P1 & $365-370$ & - & - & $\times$ \\
\hline G4-P1 118-123 & G4 & P1 & $118-123$ & ++ & + & - \\
\hline G5A-P1 265-270 & G5A & P1 & $265-270$ & ++ & + & - \\
\hline G6-P1 265-270 & G6 & P1 & $265-270$ & - & + & $\times$ \\
\hline G10-P2 065-070 & G10 & P2 & $65-70$ & ++ & + & + \\
\hline G15-P1 215-220 & G15 & P1 & $215-220$ & ++ & + & - \\
\hline G17-P1 065-070 & G17 & P1 & $65-70$ & ++ & + & + \\
\hline G19-P1 215-220 & G19 & P1 & $215-220$ & - & + & - \\
\hline G21-P1 315-320 & G21 & P1 & $315-320$ & + & + & $\times$ \\
\hline G22-P1 468-473 & G22 & P1 & $468-473$ & ++ & + & - \\
\hline G23-P1 315-320 & G23 & P1 & $315-320$ & + & + & $\times$ \\
\hline G23-P1 365-370 & G23 & P1 & $365-370$ & + & $\times$ & $\times$ \\
\hline G23-P1 415-420 & G23 & P1 & $415-420$ & - & $\times$ & $\times$ \\
\hline G24-P1 418-423 & G24 & P1 & $418-423$ & - & - & $\times$ \\
\hline N4-P1 518-523 & N4 & P1 & $518-523$ & ++ & + & + \\
\hline N6-P1 418-423 & N6 & P1 & $418-423$ & ++ & $\times$ & + \\
\hline N9-P1 268-273 & N9 & P1 & $268-273$ & ++ & - & $\times$ \\
\hline N13-P1 518-523 & N13 & P1 & $518-523$ & ++ & + & $\times$ \\
\hline
\end{tabular}

$++=$ relatively abundant or high concentration.

$+=$ common

- = low abundance.

$x=$ absence 
at station G1, however it only varies very limitedly at other stations (Fig. 8); this may be due to the relatively short lengths of these cores. The bulk density of the sediments show limited variations with core depth (Fig. 9). At station G21 the bulk density decreases slightly with core depth but it increases with increasing depth at station G23.

The water content of sediments shows limited variations with core depth (Fig. 10) at all studied stations except station N6 where an increase of water content with core depth was observed, probably related to the increase of chlorite ( \pm kaolinite) content with core depths (Fig. 2). There is a positive correlation between the water contents and porosities of cored sediments (Fig. 11). Among the sampling stations, G21 and G23 sediments have higher porosity and water content and G2 sediments have relatively low porosity and water content.

The bulk density of cored sediments decreases with increasing water content (Fig. 12) and porosity (Fig. 13). Station G21 and G23 sediments have relatively low bulk densities, but higher porosities, and the reverse is true for G2 sediments. Some samples contain high water contents and porosity but also have relatively high bulk density (Table 2). This may be due to the occurrence of heavy minerals.

The $\mathrm{CH}_{4}$ contents in the cored sediments were analyzed by Chuang et al. (2006). The average $\mathrm{CH}_{4}$ content of $\mathrm{G} 23$ sediments reaches $81285.2 \mu \mathrm{L} \mathrm{L}^{-1}$ with the highest value (133354.0 $\left.\mu \mathrm{L} \mathrm{L}^{-1}\right)$ occurring at a depth of $325 \mathrm{~cm}$. The sediments cored at stations G17, G21, and G22 also contain high $\mathrm{CH}_{4}$. At station $\mathrm{G} 21, \mathrm{CH}_{4}$ reaches $20703.0 \mu \mathrm{L} \mathrm{L}^{-1}$ at a depth of $275 \mathrm{~cm}$, while at station G17 it reaches $24699.0 \mu \mathrm{L} \mathrm{L}^{-1}$ at a depth of $75 \mathrm{~cm}$. High $\mathrm{CH}_{4}$ contents are found at station $\mathrm{N} 8$ and reaches $111628.0 \mu \mathrm{L} \mathrm{L}^{-1}$ at a depth of $181 \sim 190 \mathrm{~cm}$. There is a weak positive correlation between $\mathrm{CH}_{4}$ contents and average porosities of the cored sediments, especially those having high values of porosity (Fig. 14).

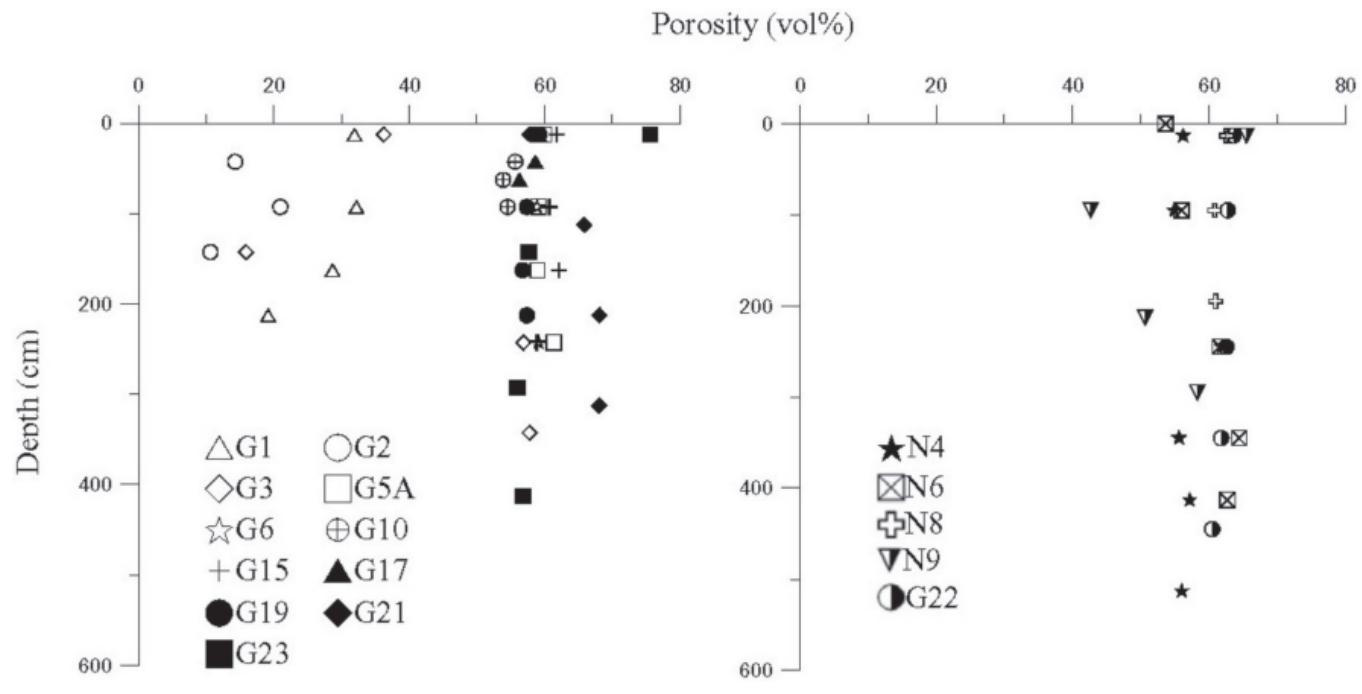

Fig. 8. The porosity variations with core depths. 


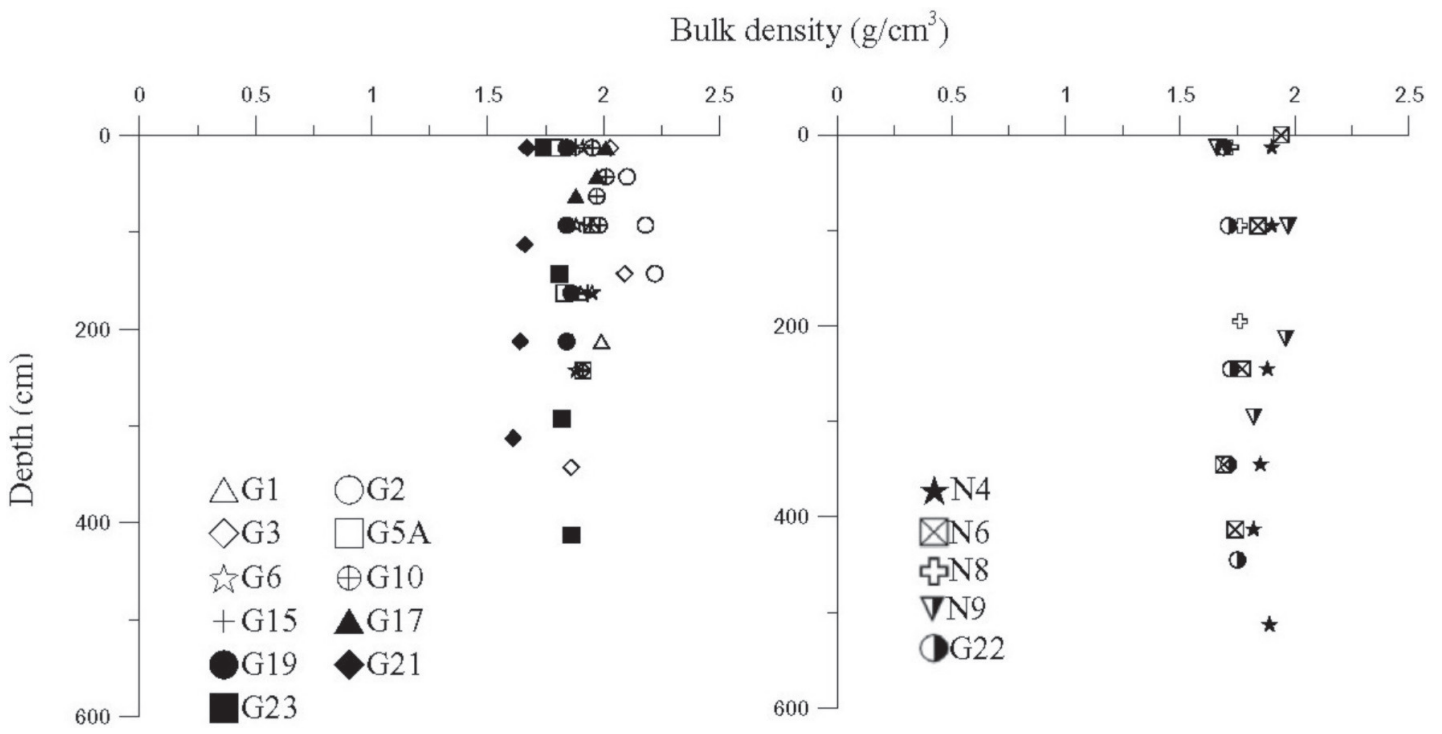

Fig. 9. The bulk density variations with core depths.

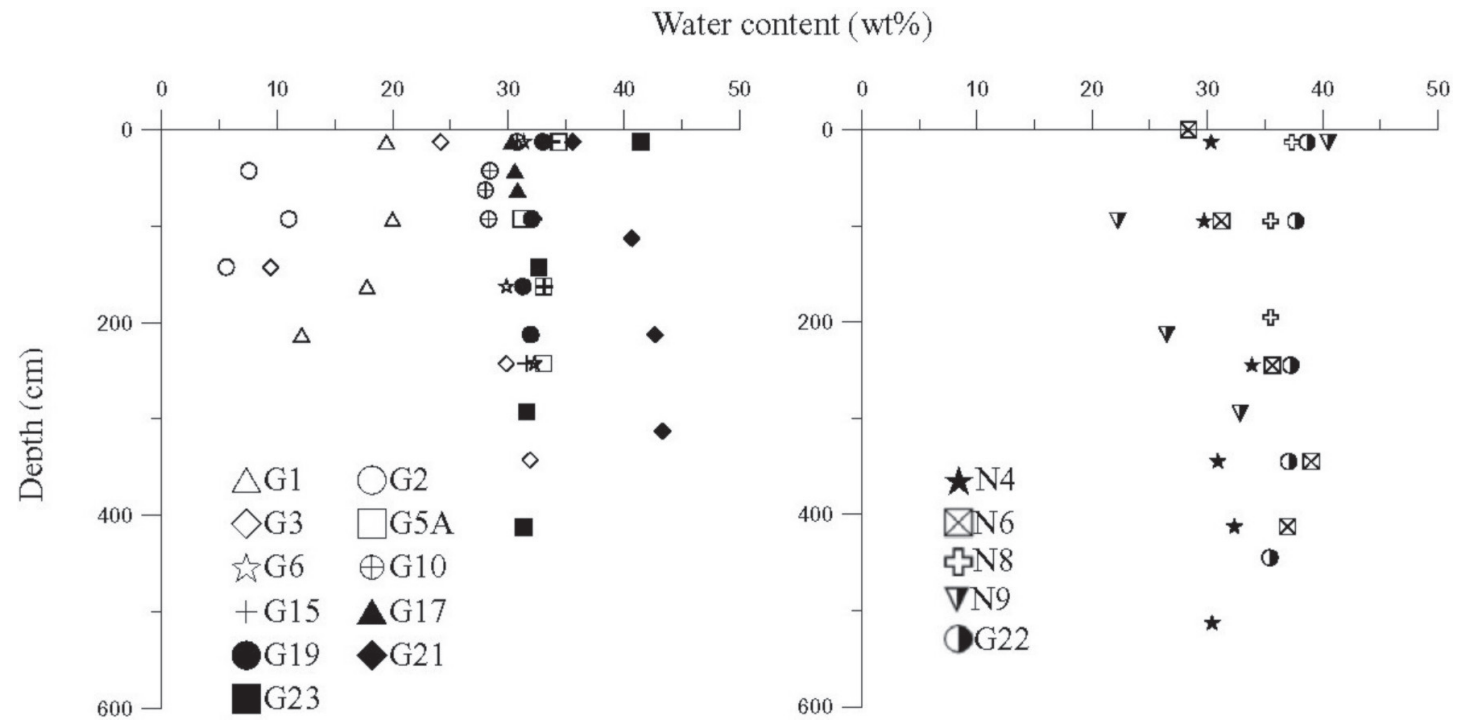

Fig. 10. The water content variations with core depths. 


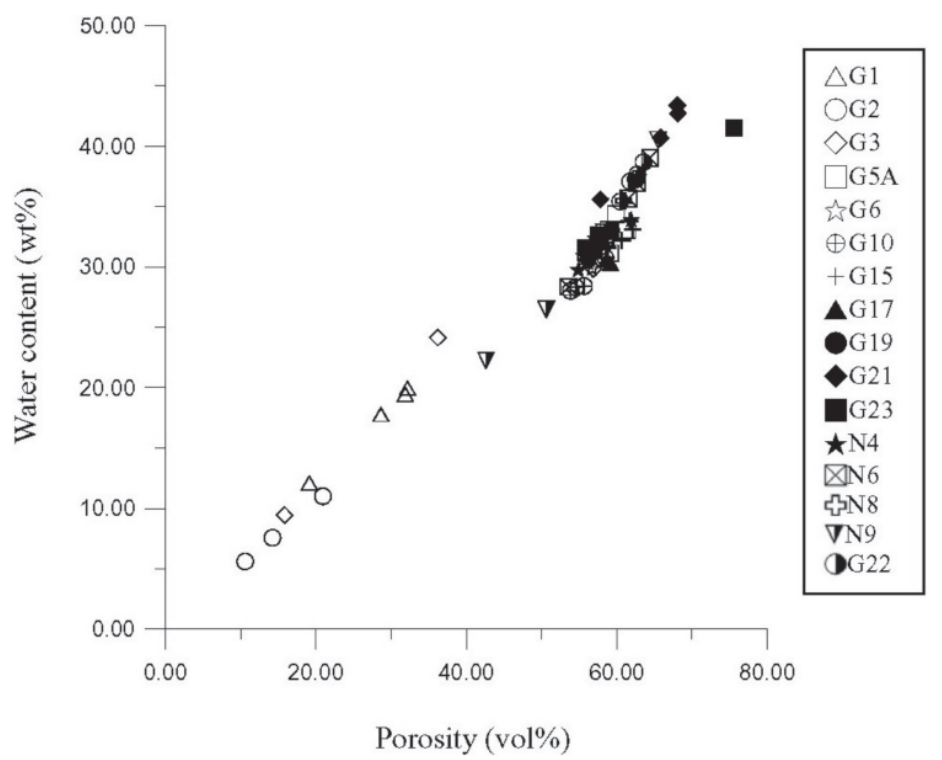

Fig. 11. Water content vs. porosity plot for cored sediments from gas-hydrate potential area off SW Taiwan.

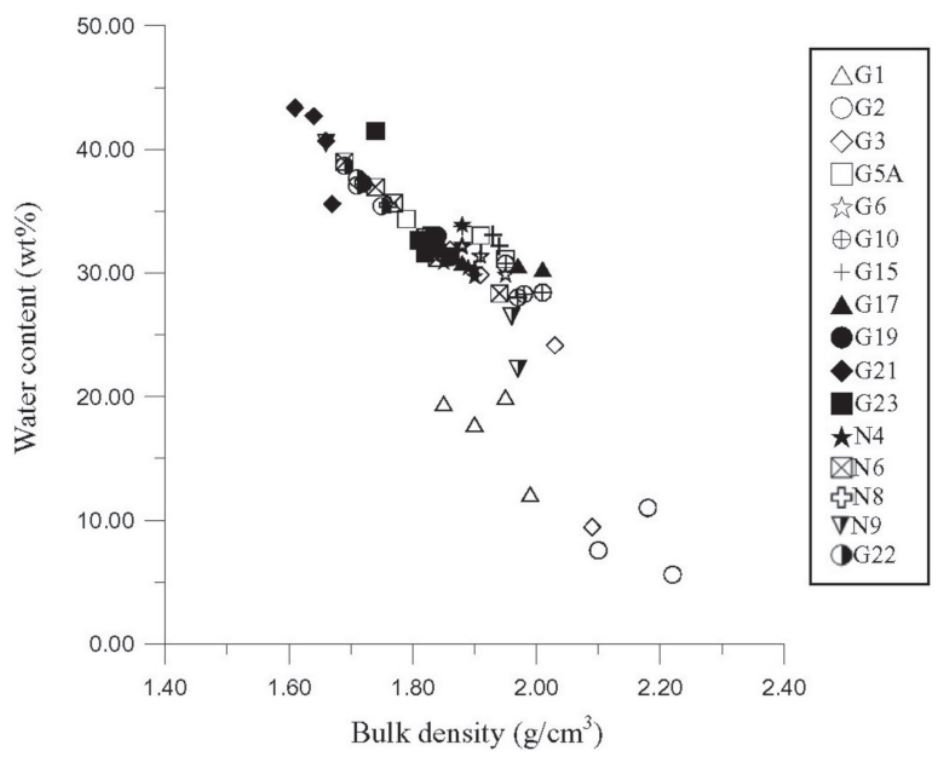

Fig. 12. Water content vs. bulk density plot for cored sediments from gas-hydrate potential area off SW Taiwan. 


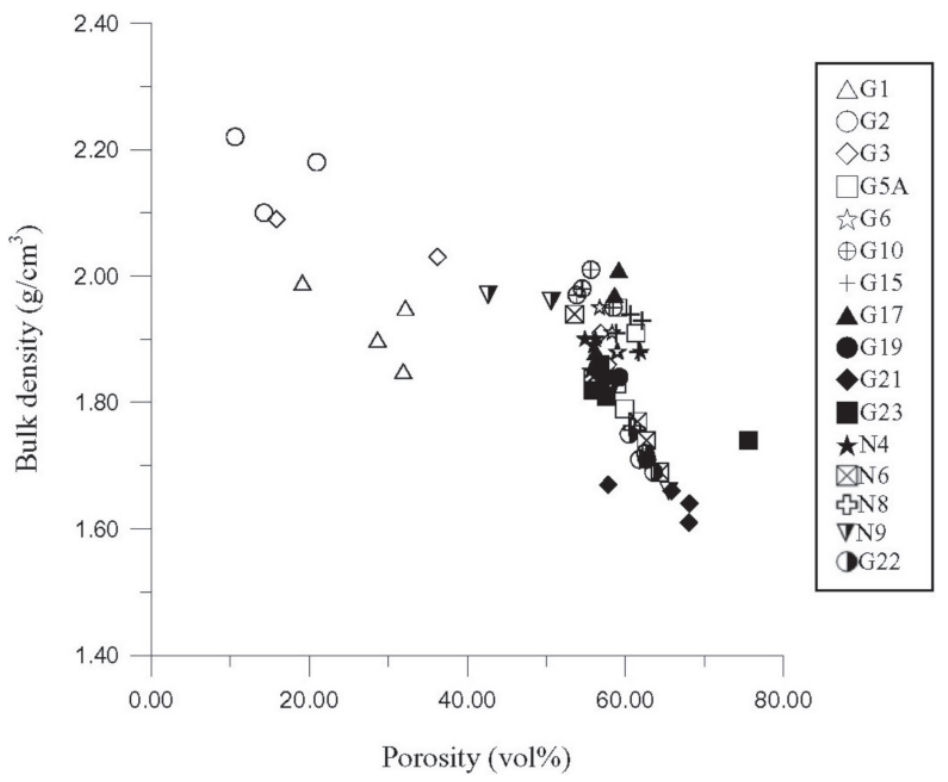

Fig. 13. Bulk density vs. porosity plot for cored sediments from gas-hydrate potential area off SW Taiwan.

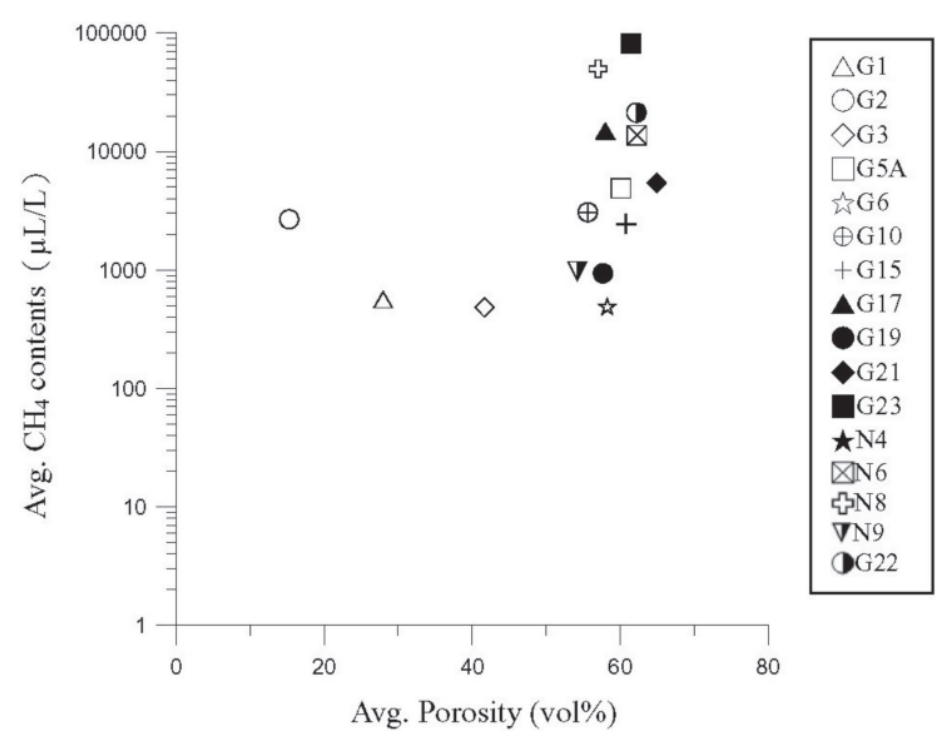

Fig. 14. Average $\mathrm{CH}_{4}$ contents (Chuang et al. 2006) vs. average porosity plot for cored sediments from gas-hydrate potential area off SW Taiwan. 


\section{DISCUSSION}

\subsection{Physical Properties and Gas Hydrate Potential}

There are clear gas escape structures in the cores at station G6 (N22 ${ }^{\circ} 13.57^{\prime}$, E119 ${ }^{\circ} 57.07^{\prime}$, water depth $567 \mathrm{~m}$ ) and another station (N22 $13.138^{\prime}$, E120 $10.243^{\prime}$, water depth $930 \mathrm{~m}$ ) located at the eastern side of the Kaoping Canyon (Fig. 15). These gas escape structures are similar to those found at Hydrate Ridge off the Oregon coast studied by ODP Leg 204 (Milkov et al. 2003), strongly indicating the occurrence of gas hydrate at these sites.

The probable reserve (PR) of gas hydrate can be estimated by the following equation (Gornitz and Fung 1994):

$$
\begin{aligned}
\operatorname{PR}\left(\mathrm{m}^{3}\right)=\text { Area }\left(\mathrm{m}^{2}\right) & \times \text { average thickness of hydrate stability zone }(\mathrm{m}) \\
& \times \text { average porosity }(\%) \times \text { saturation index }(\%) \\
& \times \text { volumetric gas expansion factor }
\end{aligned}
$$

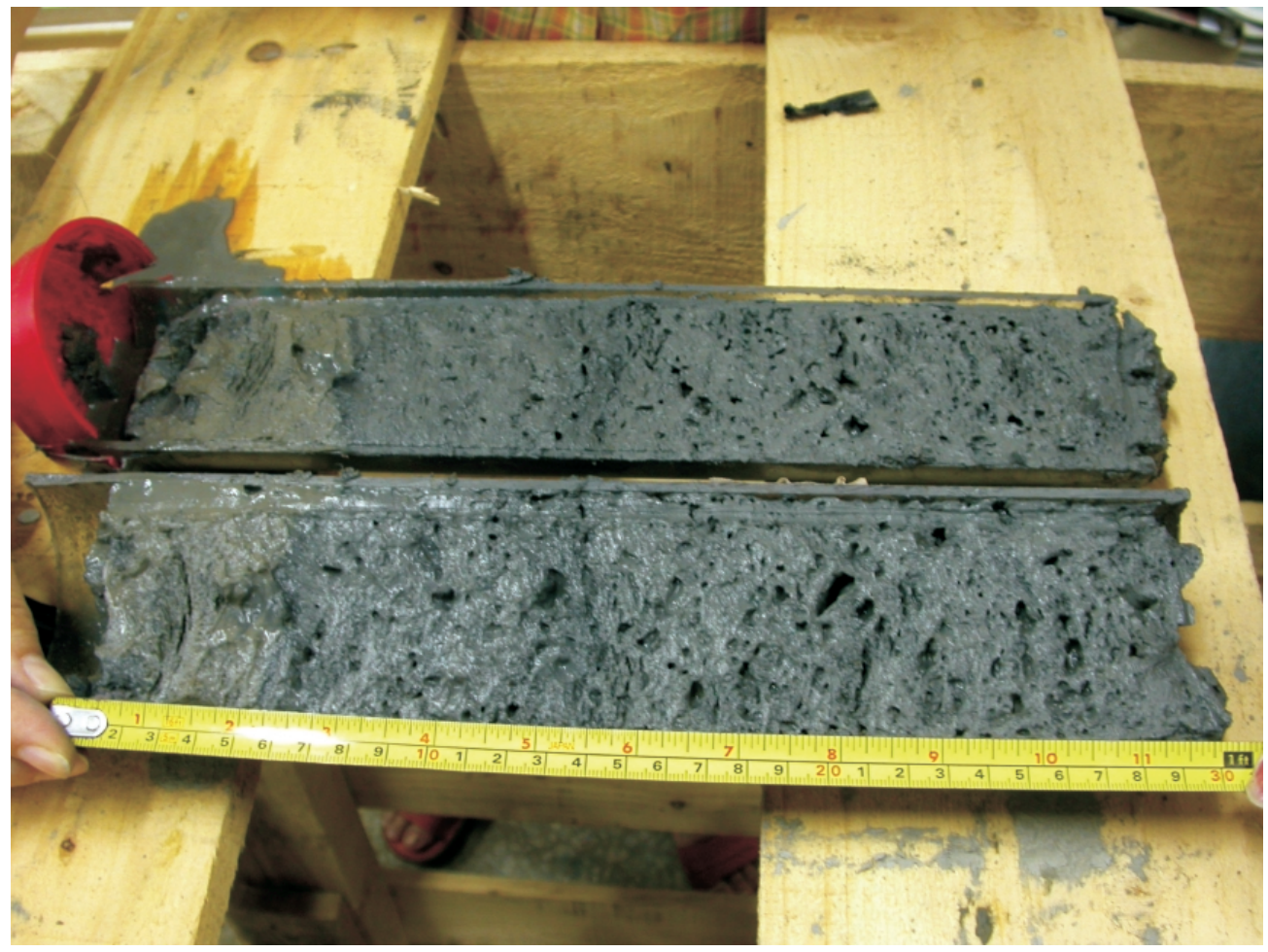

Fig. 15. Gas escape structures in the core taken at N22 ${ }^{\circ} 13.138^{\prime}, \mathrm{E} 120^{\circ} 10.243^{\circ}$, (water depth $930 \mathrm{~m}$ ) located at the eastern side of the Kaoping Canyon (photo by courtesy of Dr. H. L. Lin). 
The volumetric gas expansion factor of methane hydrate to methane is the volume of $\mathrm{CH}_{4}$ released by unit gas hydrate at $0^{\circ} \mathrm{C}$ and $1 \mathrm{~atm}$ and is estimated to be 170 by Gornitz and Fung (1994). The porosity of the cored sediments in the present study shows wider variations than the Taiwan Strait shelf sediments studied by Chen (1981) which range from 35 to $55 \mathrm{~V} \%$. The higher porosity found in the present cored sediments is an advantage to occurrence of gas hydrate.

A firm conclusion with respect to the depth of the gas-hydrate reservoir offshore SW Taiwan cannot be ascertained at the present stage, but from the aforementioned equation it is apparent that the porosity of sediments plays an important role in the existence of methane in sediments, although the presence of other gases such as $\mathrm{CO}_{2}, \mathrm{C}_{2} \mathrm{H}_{6}$, etc., may have certain influences. In the accretionary wedge, the porosity of sediments in general tends to decrease with depth due to compressional stress. In the Nankai accretionary wedge (Shipboard Scientific Party 2002) and the Cascadia prism (Jarrard 1995), the porosity of the sediments near the seabed is generally around $65-75 \%$, however it tends to decrease 5\% per every $100 \mathrm{~m}$ depth. Far away from the deformation front in the accretionary wedge, the porosity of sediments tends to decrease due to compressional deformation. In a restricted area where thrust faults and shear zones exist, the porosity reduction may occur due to shear dewatering. The sedimentation rate, grain-size distribution, clay-mineral and organic-matter contents may also be the controlling factors of sediment porosity. Sediment porosity increases when the proportion of fine-grained fractions increases in general.

The terrigenous sediments deposited on the Kaoping shelf and the upper part of the Kaoping slope during Quaternary may reach 2000 to 3000 meters thick (Yu and Huang 2006). These terrigenous sediments were mainly derived from Taiwan Island and were transported southwestward to the shelf and slope regions. These sediments are relatively rich in organic contents (TOC averaging 0.5\%, Lin et al. 2006) and were deposited rapidly (around $0.5 \mathrm{~cm} \mathrm{yr}^{-1}$, $\mathrm{Yu}$ and Liu 2004) in the target area suitable for the formation of gas hydrate. Shyu et al. (1998) based on heat flow data suggested that $\mathrm{CH}_{4}$ may reach $90 \%$ or more of the gas hydrate in the seafloor sediments off SW Taiwan.

\subsection{Mineralogy and Sediment Sources}

Chen (1983) concluded that the upper part of the Kaoping slope is relatively unstable, if the slope angle reaches $7^{\circ}$ or larger, slumping may occur and cause relatively rapid sediment transport and sedimentation of turbidites in the target area. The occurrence of minor amounts of biotite, amphibole, olivine, and saponite in the cored sediments indicate the possibility of igneous contribution. In addition, in some core samples the montmorillonite content is high which may indicate transformation from volcanic materials. The grain-size sorting of the cored sediments are mostly poor (S.D. $=1.00 \sim 2.00 \phi$; Ju-Chin Chen, unpublished data), which together with the occurrence of olivine, amphibole and biotite suggests that the transport distance of these terrigenous sediments may be relatively limited since these ferromagnesion minerals will decompose after prolonged transportation.

The clay-mineral contents and other characteristics of the sediments analyzed in this study are similar to those of Pleistocene to Miocene rocks exposed in the regions of the Western 
Hills and Central Range of Taiwan (Hsueh and Williams 1985; Manius et al. 1985; Chamley et al. 1993), implying that the sediment source is mainly from Taiwan. The smectite content is relatively rich in the sediments cored from the western side of the target area, which is probably a result of long transportation. The XRD result of clay fractions shows that the types of clay minerals in the sediments remain unchanged regardless of sampling position and depth. Those clay minerals are most likely detrital in origin and cannot provide evidence for possible migration of clay particles from depths via mud diapirs/volcanoes.

\subsection{Implications of Authigenic Pyrite}

Pyrite is a common authigenic mineral in marine sediments. Formation of pyrite is related to sulfate reduction and oxidation and degradation of organic matter (Berner 1970, 1984; Froelich et al. 1979; Rickard et al. 1995; Böttcher and Lepland 2000). The degree of pyritization and textural features of early diagenetic pyrite are commonly used as indicators of geochemical environments (Raiswell et al. 1988; Passier et al. 1997; Wignall and Newton 1998; Wilkin et al. 1996, 1997; Wilkin and Authur 2001; Anderson and Raiswell 2004). Framboidal pyrite is believed to precipitate from iron-dominated pore waters probably via prior formation of iron monosulfide intermediates at sites of sulfide supply where the sulfide production rates were high and pore waters reached supersaturation with respect to FeS (Sweeney and Kaplan 1973; Morse et al. 1987; Roberts and Turner 1993). Euhedral pyrite precipitated directly from irondominated pore waters when $\mathrm{FeS}_{2}$ saturation was reached and sulfide production rates from organic matter were not high enough to reach FeS saturation (Goldhaber and Kaplan 1974; Raiswell 1982; Wang and Morse 1996; Rickard 1997). These two types of textural features of pyrite are common in marine sediments. The pyrite observed in the target area displays both types of microstructures and is apparently early diagenetic in origin. However, the occurrence of prominent overgrowth features over pyrite framboids at such shallow depths is rather intriguing. Such features are probably related to reducing chemical conditions that were created by further degradation of hydrocarbon originateds either from sedimentary organic matter or from gas hydrate released at depths in later stages. The existence of relatively high organic-matter contents in the sediments (Lin et al. 2004) is consistent with reduction of sulfate by organic matter. On the other hand, rapid downward decrease in sulfate concentrations to near zero, and increase of methane concentrations in pore waters over small depth intervals at several stations (Lin et al. 2006) and the presence of large amounts of methane in core-top waters at many sites in the target area (Yang et al. 2006) seem to strongly support the hypothesis of sulfate reduction relating to gas hydrate migration.

\section{CONCLUSION}

An explorative survey was carried out to measure the physical properties and mineralogical characteristics of cored sediments from the gas hydrate prospect area in offshore southwestern Taiwan. These sediments have porosities of 10.60 - 75.54 vol.\%, water contents of 5.61 $43.37 \%$, and bulk densities of $1.61-2.22 \mathrm{~g} \mathrm{~cm}^{-1}$, comparable to sediments in other regions with gas hydrate occurrence (Sun and Goldberg 2005). Relatively poor sorting and mineral- 
ogy of detrital materials and clay fractions imply short-distance transport and rapid sedimentation of the sediments. These factors together with the organic-rich nature of the sediments indicate a favorable environment for the formation of gas hydrates. In addition, the high methane concentrations in core-top waters and sediment porewaters and the presence of gasescape structures further imply possible occurrence and migration of gas hydrates in the target area. Observation of prominent overgrowth microstructures on authigenic pyrite framboids at shallow depths appears to be consistent with further sulfate reduction and pyrite precipitation by oxidation of methane hydrates released from potential gas hydrate zones at later stages of early diagenesis.

Acknowledgements We are grateful to T. F. Yang for providing measurements methane concentrations and H. L. Lin for giving the photo of gas-escape structures in cored sediments. We thank S. Lin, T. F. Yang, C. S. Horng, C. Y. Huang, and C. F. You for their helpful discussion. Many thanks are given to C. S. Liu, P. Schnürle, and S. Lin for their help on selection of sampling sites. This work is supported by the Central Geological Survey of the Ministry of Economic Affairs of the Republic of China under grant 5226902000-06-93-02 to JCC and WTJ and by National Science Council under grant NSC93-2116-M-006-002 to WTJ. Dr. Sam Boggs of the University of Oregon critically reviewed the early version of the manuscript, which improved the paper substantially. We thank Dr. Ulrich Knittel and an anonymous reviewer for their critical reviews.

\section{REFERENCES}

Anderson, T. F., and R. Raiswell, 2004: Sources and mechanisms for the enrichment of highly reactive iron in euxinic Black Sea sediments. Am. J. Sci., 304, 203-233.

Berner, R. A., 1970: Sedimentary pyrite formation. Am. J. Sci., 268, 1-23.

Berner, R. A., 1984: Sedimentary pyrite formation: an update. Geochim. Cosmochim. Acta, 48, 605-615.

Biscaye, P. E., 1965: Mineralogy and sedimentation of recent deep-sea clay in the Atlantic Ocean and adjacent seas and oceans. Geol. Soc. Am. Bull., 76, 803-832.

Böttcher, M. E., and A. Lepland, 2000: Biogeochemistry of sulfur in a sediment core from the west-central Baltic Sea: evidence from stable isotopes and pyrite textures. J. Mar. Syst., 25, 299-312.

Bowin, C., R. S. Lu, C. S. Lee, and H. C. Schouten, 1978: Plate convergence and accretion in Taiwan-Luzon region. AAPG Bull., 62, 1645-1672.

Chamley, H., J. Angelier, and L. S. Teng, 1993: Tectonic and environmental control of the clay mineral sedimentation in the late Cenozoic orogen of Taiwan. Geodin. Acta, 6 , $135-147$.

Chen, M. P. 1981: Geotechnical properties of sediments off the coast of Hsinchu-northwest Taiwan related to sedimentary environment. Acta Oceanogr. Taiwan., 12, 28-53.

Chen, M. P., 1983: Physical properties and deformational environment of marine sediments 
from the continental slope, south of the Taiwan strait. Acta Oceangr. Taiwan., 14, $42-63$.

Chuang, P. C., T. F. Yang, S. Lin, H. F. Lee, T. F. Lan, W. L. Hong, C. S. Liu, J. C. Chen, and Y. Wang, 2006: Extremely high methane concentration in bottom water and cored sediments from offshore southwestern Taiwan. Terr. Atmos. Ocean. Sci., 17, 903-920.

Froelich, P. N., G. P. Klinkhammer, M. L. Bender, N. A. Luedtke, G. R. Heath, D. Gullen, P. Dauphin, D. Hammond, B. Hartman, and V. Maynard, 1979: Early oxidation of organic matter in pelagic sediments of the eastern equatorial Atlantic: suboxic diagenesis. Geochim. Cosmochim. Acta, 43, 1075-1090.

Fu, S. C., C. S. Liu, and M. S. Wu, 1997: Migration of canyon systems from Pleistocene in area between Hsyning structure and Kaoping slope and its application for hydrocarbon exploration. Petrol. Geol. Taiwan, 31, 43-60.

Goldhaber, M. B., and I. R. Kaplan, 1974: The sulfur cycle. In: Goldberg, E. D. (Ed.), The Sea, Volume 5. Wiley, New York, 569-655.

Gornitz, V., and I. Fung, 1994: Potential distribution of methane hydrate in the world's oceans. Global Biogeochem. Cycles, 8, 335-347.

Horng, C. S., 2005: Rock magnetism of Sediments off southwestern Taiwan. Geological investigation and geochemical exploration off SW Taiwan (2/4). Report of Central Geological Survey Project 5226902000-05-94-02, Minist. Econ., 35 pp. (in Chinese)

Hsueh, C. M., and D. J. William, 1985: Diagenesis of organic materials and clay in the Neogene sediments of western Taiwan. Petrol. Geol. Taiwan, 21, 129-171.

Huang, C. Y., W. Y. Wu, C. P. Chang, S. Taso, P. B. Yuan, C. W. Lin, and K. Y. Xia, 1997: Tectonic evolution of accretionary prism in the arc-continent collision tenane of Taiwan. Tectonophysics, 281, 31-51.

Huang, C. Y., P. B. Yuan, C. W. Lin, T. K. Wang, and C. P. Chang, 2000: Geodynamic processes of Taiwan arc-continent collision and comparesion with analogs in Timor, Pagua New Guinea, Urals and Corsica. Tectonophysics, 325, 1-21.

Huang, C. Y., H. Li, and C. W. Chien, 2004: Characteristics of sediments and foraminafers in gas hydrate high potentiall area off SW Taiwan. Proc. Int. Workshop Gas Hydrate Explor. Exploit., 53-58.

Jarrard, R. D., 1995: Log-based porosity of ODP sites of the Cascadia accretionary prism. Proc. Ocean Drilling Prog., Sci. Res., 146, 313-335.

Johns, W. D., R. E. Grim, and W. F. Bradley, 1954: Quantitative estimations of clay minerals by diffraction methods. J. Sediment. Petrol., 24, 242-251.

Kunze, G. W., and J. B. Dixon, 1986: Pretreatment for mineralogical analysis. In: Klute, A. (Ed.), Methods of Soil Analysis, Part 1. Physical and Mineralogical Methods, $2^{\text {nd }}$ Ed., Soil Science Society of America Book Series 5, 91-100.

Le Roy, L. W., D. O. Le Roy, and J. W. Raese, 1977: Subsurface geology: Petroleum, Mining, Construction. Colorado School of Mines, Golden, Colorado, 941 pp.

Lin, S., W. C. Hsieh, C. S. Lin, and T. F. Yang, 2004: Consequences of gas migration and gas hydrate formation on sulfate reduction in the Good Weather Ridge sediments, SW Taiwan. Proc. Int. Workshop Gas Hydrate Explor. Exploit., 51-52.

Lin, S., W. C. Hsieh, Y. C. Lim, T. F. Yang, C. S. Liu, and Y. Wang, 2006: Methane migration and its influence on sulfate reduction in the Good Weather Ridge region, South China Sea continental margin sediments. Terr. Atmos. Ocean. Sci., 17, 883-902. 
Liu, C. S., I. L. Huang, and L. S. Teng, 1997: Structural features off southwestern Taiwan. Mar. Geol., 137, 305-319.

Liu, C. S., P. Schnürle, Y. Wang, S. H. Chung, S. C. Chen, and T. H. Hsiuan, 2006: Distribution and characters of gas hydrate offshore of southwestern Taiwan. Terr. Atmos. Ocean. Sci., 17, 615-644.

Manius, W. G., M. Covey, and R. Stallard, 1985: The effects of provenance and diagenesis on clay content and crystallinity in Miocene through Pleistocene deposits, southwestern Taiwan. Petrol. Geol. Taiwan, 21, 173-185.

Matsumoto, R., H. Tomaru, and H. Lu, 2004: Detection and evaluation of gas hydrates in the eastern Nankai Trough by geochemical and geophysical methods. Resour. Geol., 54, 53-67.

Milkov, A. V., G. E. Claypool, Y. J. Lee, W. Y. Xu, G. R. Dickens, W. S. Borowski, and ODP Leg 204 Scientific Party, 2003: In situ methane concentrations at Hydrate Ridge, offshore Oregon: new constraints on the global gas hydrate inventory from an active margin. Geology, 31, 833-836.

Moore, D. M., and R. C. Reynolds, Jr., 1989: X-ray Diffraction and the Identification and Analysis of Clay Minerals. Oxford Univ. Press, New York, 332 pp.

Morse, J. W., F. J. Millero, J. C. Cornwell, and D. Rickard, 1987: The chemistry of the hydrogen sulfide and iron sulfide systems in natural waters. Earth-Sci. Rev., 24, 1-42.

Passier, H. F., J. J. Middelburg, G. J. de Lange, and M. E. Bottcher, 1997: Pyrite contents, microtextures, and sulfur isotopes in relation to formation of the youngest eastern Mediterranean sapropel. Geology, 25, 519-522.

Raiswell, R., 1982: Pyrite texture, isotopic composition and the availability of iron. Am.J. Sci., 282, 1244-1263.

Raiswell, R., F. Buckley, R. A. Berner, T. F. Anderson, 1988: Degree of pyritisation of iron as a paleoenvironmental indicator of bottom water oxygenation. J. Sediment. Petrol., 58, 812-819.

Rickard, D., 1997: Kinetics of pyrite formation by the $\mathrm{H}_{2} \mathrm{~S}$ oxidation of iron (II) monosulfide in aqueous solutions between 25 and $125^{\circ} \mathrm{C}$ : the rate equation. Geochim. Cosmochim. Acta, 61, 115-134.

Rickard, D., M. A. A. Schoonen, and G. W. Luther, III, 1995: The chemistry of iron sulfides in sedimentary environments. In: Vairavamurthy, V., and M. A. A. Schoonen (Eds.), Geochemical Transformations of Sedimentary Sulfur. American Chemical Society Symposium Series, 612, 168-193.

Roberts, A. P., and G. M. Turner, 1993: Diagenetic formation of ferromagnetic iron sulphide minerals in rapidly deposited marine sediments, South Island, New Zealand. Earth Planet. Sci. Lett., 115, 257-273.

Schnürle, P., C. S. Liu, and C. S. Lee, 2006: Acoustic and shear-wave velocities in hydratebearing sediments offshore southwestern Taiwan: tomography, converted waves analysis and reverse-time migration of OBS records. Terr. Atmos. Ocean. Sci., 17, 757-779.

Shiphoard Scientific Party, 2002: Leg196 summary. Deformation and fluid flow processes in the Nankai Trough accretionary prism: Logging while drilling and advanced CORKS. Proc. Ocean Drilling Prog., Init. Rep., 196, 1-29.

Shyu, C. H., S. K. Hsu, and C. S. Liu, 1998: Heat flows off southwestern Taiwan: measure- 
ment over mud diapers and estimated from bottom-simulating reflectors. Terr. Atmos. Ocean. Sci., 9, 795-821.

Sun, S. C., and C. S. Liu, 1993: Mud diapers and submarine channel deposits in offshore Kaohisung-Hengchun, southwest Taiwan. Petrol. Geol. Taiwan, 28, 1-14.

Sun, Y. F., and D. Goldberg, 2005: Dielectric method of high-resolution gas hydrate estimation. Geophys. Res. Lett., 32, L04313, doi:10.1029/2004GL021976.

Suppe, J., 1984: Kinematics of arc-continent collision, flipping of subduction and back-arc spreading near Taiwan. Mem. Geol. Soc. China, 6, 21-33.

Sweeney, R. E., and I. R. Kaplan, 1973: Pyrite framboid formation: laboratory synthesis and marine sediments. Econ. Geol., 68, 618-634.

Wang, Q., and J. W. Morse, 1996: Pyrite formation under conditions approximating those in anoxic sediments I. Pathways and morphology. Mar. Chem., 52, 99-121.

Whittig, L. D., and W. R. Allardice, 1986: X-ray diffraction techniques. In: Klute, A. (Ed.), Methods of Soil Analysis, Part 1. Physical and Mineralogical Methods, $2^{\text {nd }}$ Ed., Soil Science Society of America Book Series 5, 331-362.

Wignall, P. B., and R. Newton, 1998: Pyrite framboid diameter as a measure of oxygen deficiency in ancient mudrocks. Am. J. Sci., 298, 537-552.

Wilkin, R. T., and M. A. Authur, 2001: Variations in pyrite texture, sulfur isotope composition, and iron systematics in the Black Sea: evidence for late Pleistocene to Holocene excursions of the $\mathrm{O}_{2}-\mathrm{H}_{2} \mathrm{~S}$ redox transition. Geochim. Cosmochim. Acta, 65, 1399-1416.

Wilkin, R. T., H. L. Barnes, and S. L. Brantley, 1996: The size distribution of framboidal pyrite in modern sediments: an indicator of redox conditions. Geochim. Cosmochim. Acta, 60, 3897-3912.

Wilkin, R. T., M. A. Authur, and W. E. Dean, 1997: History of water-column anoxia in the Black sea indicated by pyrite. Earth Planet. Sci. Lett., 148, 517-525.

Yang, T. F., P. C. Chuang, S. Lin, J. C. Chen, Y. Wang, and S. H. Chung, 2006: Methane venting in gas hydrate potential area offshore of SW Taiwan: evidence of gas analysis of water column samples. Terr. Atmos. Ocean. Sci., 17, 933-950.

Yu, H. S., and Z. Y. Huang, 2006: Intraslope basin, seismic facies and sedimentary processes in the Kaoping slope, offshore southwestern Taiwan. Terr. Atmos. Ocean. Sci., 17, 659-677.

Jiang, W. T., J. C. Chen, B. J. Huang, C. J. Chen, Y. T. Lee, P. R. Huang, C. C. Lung, and S. W. Huang, 2006: Mineralogy and physical properties of cored sediments from the gas hydrate potential area of offshore southwestern Taiwan. Terr. Atmos. Ocean. Sci., 17, 981-1007. 